\title{
Deletion of the Mucin-Like Molecule Muc1 Enhances Dendritic Cell Activation in Response to Toll-Like Receptor Ligands
}

\author{
Marc A. Williams ${ }^{a, b}$ Stephen Bauer ${ }^{a}$ Wenju Lu ${ }^{d} \quad$ Jia Guo ${ }^{a} \quad$ Scott Walter ${ }^{a}$ \\ Timothy P. Bushnell ${ }^{c}$ Erik P. Lillehoj ${ }^{\mathrm{e}}$ Steve N. Georas ${ }^{\mathrm{a}, \mathrm{b}}$ \\ ${ }^{a}$ Division of Pulmonary and Critical Care Medicine, ${ }^{b}$ Department of Environmental Medicine, and ${ }^{c}$ Department \\ of Pediatric Biomedical Research, University of Rochester School of Medicine and Dentistry, Rochester, N.Y., \\ ${ }^{\mathrm{d}}$ Division of Pulmonary and Critical Care Medicine, Johns Hopkins University School of Medicine, and \\ eDepartment of Pediatrics, School of Medicine, University of Maryland Baltimore, Baltimore, Md., USA
}

\section{Key Words}

Inflammation - Dendritic cells • Muc1 - Toll-like receptor • Innate immunity $\cdot$ Immunomodulation $\cdot$ Host defence $\cdot$ Cytokines

\begin{abstract}
Dendritic cells (DC) are potent professional antigen-presenting cells that drive primary immune responses to infections or other agonists perceived as 'dangerous'. Muc1 is the only cell surface mucin or MUC gene product that is expressed in DC. Unlike other members of this glycoprotein family, Muc1 possesses a unique cytosolic region capable of signal transduction and attenuating toll-like receptor (TLR) activation. The expression and function of Muc1 has been intensively investigated on epithelial and tumor cells, but relatively little is known about its function on DC. We hypothesized that Muc1 would influence in vitro generation and primary DC activation in response to the TLR4 and TLR5 ligands lipopolysaccharide and flagellin. Compared with $\mathrm{MuCl}^{+/+} \mathrm{DC}$, we found that $\mathrm{MuC1}^{-/-} \mathrm{DC}$ were constitutively activated, as determined by higher expression of co-stimulatory molecules (CD40, CD80 and CD86), greater secretion of immunoregulatory cytokines (TNF- $\alpha$ and VEGF), and better stimulation of allogeneic naïve $\mathrm{CD} 4+\mathrm{T}$ cell proliferation. After activation by
\end{abstract}

either LPS or flagellin and co-culture with allogeneic CD4+ T cells, $\mathrm{Mucl}^{-/-} \mathrm{DC}$ also induced greater secretion of TNF- $\alpha$ and IFN- $\gamma$ compared to similarly activated $\mathrm{Muc}^{+/+} \mathrm{DC}$. Taken together, our results indicate that deletion of Muc1 promotes a heightened functional response of $D C$ in response to TLR4 and TLR5 signaling pathways, and suggests a previously under-appreciated role for Muc1 in regulating innate immune responses of DC.

Copyright $\odot 2009$ S. Karger AG, Basel

\section{Introduction}

Dendritic cells (DC) evolved to respond rapidly to infections or cellular damage. Conserved microbial-derived proteins and cellular fragments (danger signals) are recognized by cells of the innate immune system including DC and promote their ability to orchestrate adaptive $\mathrm{T}$ cell-mediated immunity [1-3]. Danger signals are transduced by different pattern recognition receptors including the toll-like receptor (TLR) family of innate immune receptors $[4,5]$. Microbial recognition by DC is achieved predominantly by occupation of cell membrane-expressed TLRs, particularly TLR2, TLR4 and TLR5 $[4,6,7]$. For example, binding of TLR4 by lipopoly-

\section{KARGER}

(C) 2009 S. Karger AG, Basel

Fax +4161306 1234

E-Mail karger@karger.ch

www.karger.com
Accessible online at: www.karger.com/jin
Dr. Marc A. Williams, Cardiopulmonary and Immunotoxicology Branch Environmental Public Health Division

National Health and Environmental Effects Research Laboratory

U.S. Environmental Protection Agency

Research Triangle Park, NC 27711 (USA), E-Mail mawilliams888@aol.com 
saccharide (LPS) stimulates the release of pro-inflammatory cytokines (e.g. TNF- $\alpha$, IL-12), enhances cell surface expression of co-stimulatory molecules (e.g. CD80 and CD86) and MHC class II receptors by activated DC and airway epithelial cells $[8,9]$. These responses of appropriately activated DC assist in the activation and clonal proliferation of naive CD4+ T cells [1-3]. Thus, DC provide a rapid functional response to diverse environmental cues that link innate and adaptive immune responses.

Mucl is a membrane-tethered transmembrane mucinlike glycoprotein that is expressed on a variety of tumor cells as well as T lymphocytes and dendritic cells [10-13]. Unique among mucin-like molecules, Mucl possesses signal transduction activity that is mediated in part by conserved tyrosine residues in its cytoplasmic tail [14]. Interestingly, Mucl was recently shown to be a receptor for Pseudomonas aeruginosa and the flagella proteins [15]. Flagellin is the major immunogenic protein of bacterial flagellum, and is a major virulence factor of Grampositive and Gram-negative bacteria. Occupation of Muc1 by flagellin was recently shown to induce phosphorylation of the cytoplasmic domain and subsequent activation of the mitogen-activated protein kinases ERK1/2 [14]. Flagellin is known to also bind TLR5 $[16,17]$ whose extracellular surface domain can recognize and discriminate different flagellins in mouse and human systems $[18,19]$. Since both Mucl and TLR5 recognize and transduce signals following occupation by flagellin, it was recently postulated that there was cross-talk between TLRdependent and Mucl-signaling pathways [20, 21]. Indeed, Mucl was recently shown to negatively regulate activation in response to diverse TLR ligands, including flagellin in airway epithelial cells and HEK 293T cells [22].

The objective of this study was to investigate the role of Mucl in innate immune responses, and specifically test the hypothesis that Mucl may regulate TLR-dependent DC activation. Here we compared different aspects of DC activation including uptake of exogenous antigen, costimulatory molecule expression, cytokine secretion and naive $\mathrm{T}$ cell stimulation using bone marrow-derived DC (BM-DC) from $\mathrm{Mucl}^{-/-}$and $\mathrm{Mucl}^{+/+}$mice as well as primary DC obtained from the lung and spleen of Muc1 knockouts as compared with their wild-type counterparts. We found that deletion of Mucl resulted in both constitutive and TLR-inducible enhancement of DC function, including a greater ability to stimulate allogeneic naive $\mathrm{CD} 4+\mathrm{T}$ cell activation in co-culture assays. Moreover, we found marked concordance in functional responsiveness of in vitro generated BM-DC as well as primary DC isolated from the lung and spleen.

\section{Materials and Methods}

\section{Generation of Murine Dendritic Cells and Stimulation}

Conventional myeloid DC were generated from bone marrowderived precursors (BM-DC) of naive $\mathrm{Mucl}^{+/+}$and $\mathrm{Mucl}^{-I_{-}}$mice on the FVB genetic background and expressing the $H-2^{q} \mathrm{MHC}$ class I haplotype, as previously described $[23,24]$. $\mathrm{Mucl}^{-1-}$ mice [22] and their $\mathrm{Mucl}^{+/+}$littermates were generously provided by Dr. K. Chul Kim (Temple University School of Medicine). Mice were euthanized by $\mathrm{CO}_{2}$ asphyxiation according to the animal experimentation policies of the Johns Hopkins University institutional animal care and use committee. Bone marrow suspensions were collected from the femurs and tibiae of 4 mice per pooled group by flushing the bone marrow cavity with $2 \mathrm{ml}$ of ice-cold complete culture medium at the femoral and tibial epiphysis. Cells were centrifuged at $400 \mathrm{~g}, 8^{\circ} \mathrm{C}$ for $10 \mathrm{~min}$ to collect the cells, and then resuspended in complete culture medium (RPMI1640 with $20 \mathrm{~mm}$ HEPES buffer, $2 \mathrm{mM}$ L-glutamine, $2.5 \mu \mathrm{g} / \mathrm{ml}$ gentamycin sulfate, $8 \% \mathrm{v} / \mathrm{v}$ FBS) by gentle pipetting. Erythrocytes were removed by lysis in AKC buffer $\left(0.15 \mathrm{M} \mathrm{NH}_{4} \mathrm{Cl}, 1.0 \mathrm{mM}\right.$ $\mathrm{KHCO}_{3}, 0.1 \mathrm{mM} \mathrm{Na}_{2}$ EDTA, pH 7.4). Cells were next seeded into 6 -well plates at $2.5 \times 10^{5}$ cells per well in a total volume of $4.0 \mathrm{ml}$ of complete culture medium and cultured at $37^{\circ} \mathrm{C}$ under $5 \% \mathrm{CO}_{2}$ in air atmosphere and a fully humidified incubator. Cultures were pulsed every 2 days for 8 days in complete RPMI-1640 culture medium, supplemented with GM-CSF (25 ng/ml) and IL-4 (10 $\mathrm{ng} / \mathrm{ml}$ ), a combination of cytokines that reproducibly propagates pure populations of myeloid DC [23-25]. Next, immature DC were harvested, centrifuged over $13.7 \% \mathrm{v} / \mathrm{v}$ iodixanol cell separation columns (to enrich still more for highly pure and highly viable immature DC) at $650 \mathrm{~g}, 20 \mathrm{~min}, 20^{\circ} \mathrm{C}$, washed and seeded at $8 \times 10^{5}$ cells $/ \mathrm{ml}$, in 12 -well culture dishes in a total volume of 2.0 $\mathrm{ml}$. DC were stimulated with culture medium alone (resting immature DC), $100 \mathrm{ng} / \mathrm{ml}$ LPS (Escherichia coli-derived endotoxin, serotype 055:B5 in endotoxin-free water) or $100 \mathrm{ng} / \mathrm{ml}$ flagellin in endotoxin-free divalent cation-free PBS with $20 \mathrm{mM}$ HEPES buffer, $\mathrm{pH}$ 7.4. The method for purifying flagellin from Pseudomonas aeruginosa strain $\mathrm{K}$ has been described [14]. Following $48 \mathrm{~h}$ of culture, we harvested DC and culture supernatant to assess cell function and secretion of cytokines. Immature DC were characterized as myeloid subset by moderate expression of the $\beta 2$-integrin CD11c (>70\% fluorescent-positive cells), high expression of MHC class II (Ia/Ie, with $>90 \%$ fluorescent-positive cells), very high expression of CD11b (>90\% fluorescent-positive cells) and absence of the lymphoid DC marker CD8 $\alpha$ and absent expression of the plasmacytoid DC-associated marker PDCA1 ( $<5.0 \%$ fluorescent-positive cells) by flow cytometry (BD FACScalibur).

\section{Procedures for Isolating Highly Pure Populations of}

Pulmonary or Splenic Myeloid DC

For these series of experiments, $\mathrm{Mucl}^{-1-}$ mice [22] and their $\mathrm{MuCl}^{+/+}$littermates were generously provided by Dr. Erik P. Lillehoj (Department of Pediatrics, School of Medicine, University of Maryland Baltimore, Baltimore, Md., USA). The isolation of highly pure populations of conventional myeloid DC from the lung has been described previously by our group in full detail [26]. In 3 separate independent experiments, we enriched for lung myeloid CD11b+ CD11c+ PDCA-1- DC (where PDCA is plasmacytoid DC Ag-1 cell surface marker). From groups of 6 mice per genotype, a crude lung tissue homogenate was depleted of con- 
taminating CD11c+ macrophages by adherence to tissue culture grade $10-\mathrm{cm}^{2}$ plastic dishes followed by positive immunomagnetic DC purification using the conventional myeloid CD11c DC direct enrichment procedure according to the manufacturer's protocol (Miltenyi Biotec, Bergisch Gladbach, Germany). Using the above protocol, from groups of $6 \mathrm{Mucl}^{+/+} \mathrm{DC}$ or $\mathrm{Mucl}^{-/-} \mathrm{DC}$, we harvested $5.7 \times 10^{5}$ to $1.7 \times 10^{6} \mathrm{CD} 11 \mathrm{c}+\mathrm{DCs}(92.3-96.4 \%$ pure by flow cytometric quantitation of CD11c expression) of purified DC [26] with a viability of $>95 \%$ by $0.02 \% \mathrm{v} / \mathrm{v}$ trypan blue exclusion. Sufficient numbers were obtained to permit basic flow cytometric, antigen uptake/endocytic and cytokine secretion functional assays as well as naive allogeneic CD4+ T cell/DC cocultures as previously described [26].

We purified splenic DC from the same pools of mice used for lung DC enrichment as describe above. In this procedure, spleens were pooled, and conventional myeloid DC purified by a 3 -stage procedure consisting of physical harvesting of a single cell suspension, then differential separation of DC over a $13.7 \% \mathrm{v} / \mathrm{v}$ iodixanol/matrizamide column followed by enrichment of CD11c expressing DC by positive selection and immunomagnetic microbead procedures (Miltenyi Biotec). Thus, single cell suspensions were obtained by subjecting pooled spleens to compression against a $70-\mu \mathrm{m}$ cell strainer using the plunger of a $10-\mathrm{ml}$ syringe placed in a $100-\mathrm{mm}$ petri dish at room temperature in complete culture medium (RPMI-1640 supplemented with $8 \% \mathrm{v} / \mathrm{v}$ FBS). The single cell suspension $(5 \mathrm{ml})$ was layered over a $5-\mathrm{ml}$ cushion of $13.7 \%$ $\mathrm{v} / \mathrm{v}$ iodixanol (usually 4 columns for 4 or 5 spleens) in a $15-\mathrm{ml}$ conical tube and centrifuged at $650 \mathrm{~g}$ for $20 \mathrm{~min}$ at $20^{\circ} \mathrm{C}$ with brakes off. This separation procedure is highly efficient at preenriching for DC since a combination of both low density and differential shrinkage of cells on exposure to iodixanol (which is hypertonic) permits DC to accumulate at the interface of the supernatant and iodixanol gradient. The interface DC were harvested and washed three times in complete culture medium at $350 \mathrm{~g}$ for $6 \mathrm{~min}$ at $20^{\circ} \mathrm{C}$. At this stage of the purification procedure and for these experiments, we obtained $9.4 \times 10^{5}$ to $1.7 \times$ $10^{6}$ interface cells per spleen or for each genotype we obtained between $5.64 \times 10^{6}$ to $10.2 \times 10^{6}$ interface cells from 6 pooled spleens. In the final part of the purification procedure, we used an immunomagnetic positive selection protocol, midiMACS magnet and LS+ columns to purify the CD11c+ myeloid splenic DC (Miltenyi Biotec). The collected column-bound DC gave a yield of 4.5-8.2 × $10^{6} \mathrm{CD} 11 \mathrm{c}+\mathrm{DC}$ from 6 pooled spleens of either genotype as well as a mean percent viability of $>99 \%$ by $0.02 \%$ $\mathrm{v} / \mathrm{v}$ trypan blue exclusion and inverted light microscopic cell counting.

\section{Western Immunoblotting for TLR5 and Muc1 Expression}

Proteins $(100 \mu \mathrm{g}$ per lane, estimated by the bicinchoninic acid method; Pierce, Rockford, Ill., USA) were subjected to standard SDS-PAGE at $20 \mathrm{~mA} / \mathrm{gel}$ in a $10 \% \mathrm{w} / \mathrm{v}$ acrylamide/bis-acrylamide resolving gel and transferred onto polyvinylidine difluoride membranes (Bio-Rad, Hercules, Calif., USA) for $2 \mathrm{~h}$ at room temperature at $100 \mathrm{~V}$. Membranes were probed for the following proteins: Muc1/mucin isoform-7, using a rabbit polyclonal N-terminal domain-specific antibody to MUC1 (clone EP1024Y; Abcam, Cambridge, Mass., USA) at 1/800 dilution and TLR5 using a rabbit polyclonal N-terminal domain-specific antibody (clone M300; Santa Cruz Biotechnology, Santa Cruz, Calif., USA) at 1/250 dilution. For all bound primary antibodies, we used a secondary goat polyclonal to rabbit IgG heavy and light chains conjugated to horseradish peroxidase (Abcam) at a dilution of 1/2,000 to $1 / 5,000$ and detection by SuperSignal enhanced chemiluminescence reagent (ECL; Pierce). The blot was washed and reprobed with a rabbit polyclonal to $\beta$-actin as an internal control of equivalent protein loading (Abcam) at 1/4,000 dilution. Blots were exposed onto autoradiographic film to visualize protein bands.

\section{Analysis of Extracellular Antigen Uptake by DC}

The uptake of FITC-conjugated dextran (FITC-DX, $40 \mathrm{kDa}$; Molecular Probes, Eugene, Oreg., USA) by resting or activated BM-DC was measured by our previously published procedure [23, 26]. Resting or activated BM-DC (as described above) were washed and then incubated in complete culture medium plus $1 \mathrm{mg} / \mathrm{ml}$ FITC-DX for $0,30,60,90,120,150,180,210$ and $240 \mathrm{~min}$ at $37^{\circ} \mathrm{C}$ (to measure energy-dependent uptake) or at $4^{\circ} \mathrm{C}$ to monitor background (non-internalized) fluorescence of cell-membrane immobilized FITC-DX that could not be taken up at this temperature. Active uptake of FITC-DX by cells at $37^{\circ} \mathrm{C}$ was determined by subtracting the background geometric mean fluorescence intensity (MFI) of BM-DC labeled with FITC-DX at $4^{\circ} \mathrm{C}$ from the MFI of FITC-DX that was specifically taken up by BM-DC at $37^{\circ} \mathrm{C}$.

\section{Confirmation of Exogenous Antigen Uptake by Imaging}

Cytofluorography (ImageStream)

Although scanning flow cytometry is a useful tool for quantitating bulk uptake of exogenous antigen (FITC-dextran) by DC, it does not confirm cytoplasmic or intracellular accumulation of that distinct form antigen that is receptor-occupied or cell surface bound. Thus, we used an independent technique to confirm internalization of exogenous FITC-DX in BM-DC using the ImageStream imaging flow cytometer. In these experiments, highly purified CD11c+ BM-DC were stimulated with either LPS or flagellin as described above, and pulsed with FITC-DX for 0, 30 and $60 \mathrm{~min}$ at $37^{\circ} \mathrm{C}$. For imaging cytofluorography, real-time images of endocytosed fluorescent molecules of FITC-DX that had accumulated in DC were acquired on the ImageStream apparatus (Amnis, Seattle, Wash., USA) using the manufacturer's acquisition software. Spectral compensation was performed as previously described $[27,28]$ and data analysis completed using the ImageStream Data Exploration and Analysis Software program (IDEAS version 3.0.245; Amnis). During data acquisition, debris or cell aggregates were excluded and cells in focus identified using bright-field gradient root-mean squared measurements. A 5-pixel eroded mask, based on the system default mask, was generated, and the intensity of the FITC signal of internalized FITC-DC within this region was measured as previously shown [29].

\section{Characterization of Cell Membrane-Expressed Maturation} Markers of DC

We used multi-parameter flow cytometry to measure expression of function-associated molecules. DC were harvested $48 \mathrm{~h}$ after stimulation and suspended in divalent cation-free PBS supplemented with $2 \% \mathrm{v} / \mathrm{v}$ FCS and $0.2 \% \mathrm{w} / \mathrm{v}$ sodium azide (FACS buffer) and stained with the following fluorochrome-conjugated monoclonal antibodies (Pharmingen, San Diego, Calif., USA): anti-MHC class II-PE (Ia/Ie haplotype), anti-CD11b-FITC, antiCD11c-PE, anti-CD54 anti-CD80-PE, anti-CD86-PE and antiCD40-PE. Data generated from BM-DC was compared with the 
expression of cell surface function-associated molecules present on resting and LPS- or flagellin-activated primary lung DC. We analyzed samples on a FACScalibur flow cytometer using CellQuest 3.1 software (BD, Franklin Lakes, N.J., USA). Data were acquired in real-time as geometric MFI. Expression of CD40, CD80 and CD86 by BM-DC is described in detail in the text. The expression of CD54 (ICAM-1) was also enumerated on lung and splenic DC since we found this adhesion/co-stimulatory molecule to be a sensitive read-out of primary lung and splenic DC on activation by LPS or flagellin. Expression of CD11c, MHC class II and CD11b were used to confirm identity of BM-DC, myeloid lung DC and splenic DC, whose expression was similar between genotypes and which did not alter markedly on activation by LPS or flagellin (data not shown).

\section{Cytokine Production on Activation of DC}

We measured cytokine concentrations in cell-free culture supernatants of highly pure populations of bone BM-DC and primary cultures of lung DC and splenic DC by commercial multiplex cytokine arrays (Bio-Plex Pro, Mouse Cytokine Multiplex Arrays; Bio-Rad). Using this system, we quantitated the secretion of the mouse chemokine (C-X-C motif) ligand 1 CXCL1 (KC), IL10 and TNF- $\alpha$ in a 3-plex system in duplicate. In addition, we measured the secretion of IL-12p 40 by a commercially available ELISA (Invitrogen-Biosource, Camarillo, Calif., USA), with limits of sensitivity of $7.5 \mathrm{pg} / \mathrm{ml}$. In BM-DC only, we were also interested in measuring the secretion of VEGF-A by a commercially available ELISA (R\&D Systems, Minneapolis, Minn., USA) with limits of sensitivity of $7.8 \mathrm{pg} / \mathrm{ml}$. We reported data as picograms of secreted product per $10^{6}$ DC. All measurements were performed according to the manufacturer's guidelines and measurements were completed in duplicate for each independent experimental measure.

\section{Procedures for Isolating Highly Pure Populations of Naive CD4+ CD62L+ T Cells}

Female $\mathrm{C} 57 \mathrm{Bl} / 6$ mice (age $8-10$ weeks) expressing the $\mathrm{H}-2^{\mathrm{b}}$ MHC haplotype were housed in dedicated pathogen-free facilities at the University of Rochester. For purposes of isolating and purifying naive CD4+ T cells, pools of 4 mice were euthanized by $\mathrm{CO}_{2}$ asphyxiation followed by cervical dislocation and removal of the superficial inguinal, lumbar, sacral, renal, axillary, brachial and cervical nodes. A single mononuclear cell suspension in complete RPMI 1640 culture medium was prepared from the lymph nodes, as previously described [26]. T cells were enriched by layering over a cushion of Lympholyte $\mathrm{M}$ at a density of $1.0875 \mathrm{~g} / \mathrm{cm}^{3}$ ( $\mathrm{pH}$ 6.9; Cedarlane Laboratories, Burlington, N.C., USA). This is a density cell separation medium specifically optimized for the isolation of viable lymphocytes from murine lymphoid cell suspensions. This procedure depleted cell debris, erythrocytes, platelets and nonviable cells from the lymphocyte preparation. The interface lymphocytes were harvested and washed twice in icecold complete culture medium and once in MACS buffer (divalent cation-free PBS supplemented with $2.5 \% \mathrm{v} / \mathrm{v}$ FBS and $2 \mathrm{~mm}$ EDTA) at $300 \mathrm{~g}$ for $10 \mathrm{~min}$ at $4^{\circ} \mathrm{C}$. Cells were then purified so that naive $\mathrm{CD} 4+\mathrm{CD} 62 \mathrm{~L}+$ helper $\mathrm{T}$ cells were obtained by an indirect immunomagnetic bead purification protocol according to the manufacturer's instructions (Miltenyi Biotec, product No. 130093-227). These cells would be used in assays of DC-mediated allo-stimulation of naive CD4+ CD62L+ T cells.
Stimulation of Naive CD62L/CD4+ Alloreactive T Cells by Flagellin-Activated DC

To determine the stimulatory function of $\mathrm{Mucl}^{-/-}$as compared with $\mathrm{Mucl}^{+/+} \mathrm{BM}-\mathrm{DC}$, both sets of DC were exposed to LPS or flagellin (both at $100 \mathrm{ng} / \mathrm{ml}$ ) for $48 \mathrm{~h}$, washed, pre-treated with $25 \mu \mathrm{g} / \mathrm{ml}$ mitomycin C (Sigma, St. Louis, Mo., USA) to block their non-specific proliferation and interference in the $\mathrm{T}$ cell proliferation assay, and extensively washed free of mitomycin C. The DC were seeded into U-bottom 96 -well plates so that they were titrated against a constant number of naive CD4+ T cells at a density of $10^{5}$ cells/well in replicates of 4 wells for every condition. The ratio of T cells to BM-DC was 1:1, 5:1, 25:1, 125:1, 625:1 and $3,125: 1$. This was done for myeloid BM-DC as well as primary DC freshly isolated from the lung or spleen, so that we could compare the stimulatory ability of DC from those 3 organs (bone marrow, lung and spleen) as well as between genotypes on activation by LPS or flagellin versus non-stimulated DC. T cell proliferation was enumerated by pulsing co-cultures with bromodeoxyuridine (BrdU) for the final $18 \mathrm{~h}$ of culture of a 4 -day co-culture. We used a colorimetric immunoassay for the quantitation of cell proliferation, based on the measurement of BrdU incorporation during DNA synthesis, according to the manufacturer's instructions (Roche Molecular Biochemicals, Mannheim, Germany). Data were expressed as mean $\Delta$ optical density units (OD at an absorbance wavelength of $450 \mathrm{~nm}$ and a reference wavelength of 690 $\mathrm{nm})$. This was calculated by subtracting the OD of the non-specific incorporation of BrdU by $\mathrm{T}$ cells that were cultured alone from the specific incorporation of BrdU by CD4+ T cells co-stimulated by DC. Cell culture supernatants were harvested after 4 days from the BM-derived, primary lung and splenic DC and naive CD4+ T cell co-cultures (1:5 ratio) and quantified for cytokine elaboration by multiplex arrays (Bio-Plex Pro, Mouse Cytokine Multiplex Arrays; Bio-Rad). Using a 4-plex system, we quantitated secretion of IFN- $\gamma$, IL-13, IL-12p40 and IL-6. We also measured the secretion of TNF- $\alpha$ separately for bone marrow, lung and splenic DC-stimulated naive CD4+ T cell co-cultures using a standard commercially available ELISA system (R\&D Systems) with limits of sensitivity of $7.8 \mathrm{pg} / \mathrm{ml}$.

\section{Data Analysis}

We expressed data as mean \pm SD and these were the product of 5-12 independent experiments, as indicated in the text, and accordingly dependent on the yield of DC obtained from bone marrow precursors. Each independent experiment utilized at least 4 pooled mice per group (between genotype comparisons and between treatments) and each independent experiment was set up in replicates as indicated in the text and figure legends. For primary spleen and lung myeloid DC studies, 3 or 4 independent experiments were set up separately and each independent experiment was the product of 6 mice per group so that sufficient yields of highly pure DC could be obtained. Comparisons between paired and unpaired data were tested for significance using 1- and 2-way ANOVA, Student's t test and post-hoc correction by the Bonferroni method. Statistical significance was set at an alpha value of at least $\mathrm{p}<0.05$, as indicated in the text. Statistical measurements were carried out using SigmaStat version 2.03 software and Microsoft Excel statistical and data analysis tools. 


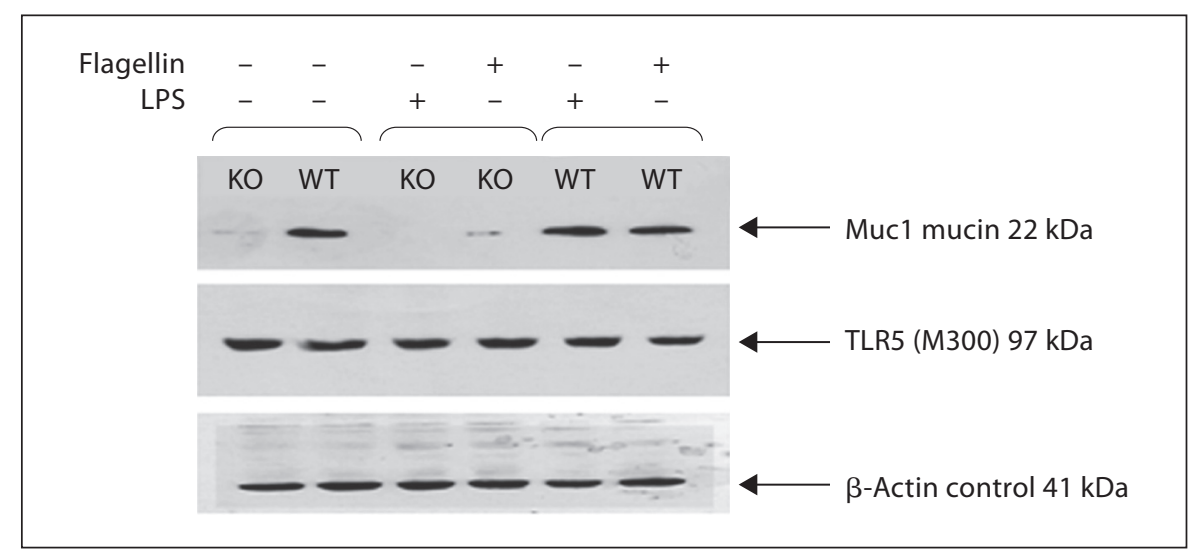

Fig. 1. Western immunoblotting images of Mucl mucin isoform 7 (clone EP1024Y), TLR5 (clone M300) and $\beta$-actin as an internal control of equivalent protein loading as detected by enhanced chemiluminescence. The expected positively staining bands of Mucl $(22 \mathrm{kDa})$ were seen for $\mathrm{Mucl}^{+/+}$DC but were absent/disrupted in normal expression in $\mathrm{Mucl}^{-/-}$DC. Expression of Muc1 was largely unaltered on activation of DC with either LPS or fla- gellin. There is evidence of non-specific protein cross-reacting with anti-Mucl clone EP1024Y. $\mathrm{Mucl}^{-/-}$mice have been confirmed to be genotypically null for expression of Mucl (data not shown $[21,22]$ ). Both $\mathrm{Mucl}^{+/+}$and $\mathrm{Mucl}^{-/-}$DCs expressed TLR5 $(97 \mathrm{kDa})$ under all conditions and the presence of $\beta$-actin confirmed equivalent protein loading on examination of the pattern of expression of these protein species.

\section{Results}

\section{Expression of TLR5 and Muc1 by DC}

By Western immunoblotting, we confirmed that wildtype but not $\mathrm{Mucl}^{-/-}$knockout DC expressed abundant Muc1 under resting conditions (fig. 1). In addition, the expression of Mucl was not affected after activation with LPS or flagellin in either $\mathrm{Mucl}^{-/-} \mathrm{DC}$ or $\mathrm{Mucl}^{+/+} \mathrm{DC}$ (fig. 1). We noted a faint Mucl immunoreactive band in DC derived from $\mathrm{Mucl}^{-1-}$ mice, which may likely represent cross-reactivity with other Mucin species by the polyclonal antibody used in these studies. By contrast, both $\mathrm{MuCl}^{-/-}$and $\mathrm{Mucl}^{+/+}$DC expressed intact TLR5 protein at rest and on activation with either LPS or flagellin (fig. 1). Thus, we confirmed that $\mathrm{MuCl}^{+/+} \mathrm{DC}$ expressed both TLR5 and Mucl, whereas $\mathrm{Mucl}^{-/-}$DC expressed TLR5 normally with disrupted Muc1 expression.

\section{Analysis of Extracellular Antigen Uptake by DC}

One of the key functions of DC is to sample their environment by taking up extracellular proteins and particulate antigens by mechanisms that include phagocytosis and endocytosis. We assessed antigen uptake by exposing resting and activated DC to exogenous low molecular weight $(40 \mathrm{kDa})$ FITC-conjugated dextran and measuring DC MFI using flow cytometry in a comprehensive analysis of time-dependent antigen uptake over a 4-hour period.
Unexpectedly, we found that resting $\mathrm{Mucl}^{+/+} \mathrm{DC}$ more efficiently took up FITC-dextran as compared with their $\mathrm{Mucl}^{-/-} \mathrm{DC}$ counterparts both at baseline and after cell stimulation (fig. 2). For example, whereas $\mathrm{Mucl}^{+/+} \mathrm{DC}$ continued to take up exogenous FITC-dextran for the duration of the assay (up to $240 \mathrm{~min}$ ), by comparison this ability remained dampened in $\mathrm{Mucl}^{-/-}$DC between 180 and 240 min (fig. 2, data expressed as geometric MFI). Although there were trends for suppressed uptake of FITC-dextran by DC after exposure to LPS and flagellin, these did not reach statistical significance (fig. 2b, c). Flow cytometric histograms from one of the experiments completed for BM-DC are also shown (fig. 2d). It can be appreciated that $\mathrm{Mucl}^{-1-}$ DC show a dampened uptake of exogenous antigen over the entire time period of this assay as compared with their wild-type DC counterparts. These data suggest that Mucl plays a previously under-appreciated role in the uptake of exogenous antigens by DC and are in keeping with a recent study implicating Mucl in lectin-mediated endocytosis [30] (see Discussion).

To confirm intracellular accumulation of FITC-dextran using an alternative approach, we next employed imaging fluorescence cytofluorography, which involves quantitative analysis of subcellular localization using an ImageStream flow cytometer (see Materials and Methods and [27-29]). Using this approach and the software associated with this technique (IDEAS version 3.0.245) we were able to distinguish membrane-bound FITC-dextran from 
intracellularly accumulated and taken up FITC-dextran, and confirmed that this material is endocytosed by both $\mathrm{Mucl}^{+/+}$and $\mathrm{Mucl}^{-/-}$BM-DC (fig. 3a-e). In the first series of measurements (fig. $3 \mathrm{a}, \mathrm{b}$ ) we validated the technique for measuring internalization of FITC-conjugated dextran particles (see Materials and Methods). In the second series of measurements, we confirmed that both $\mathrm{Mucl}^{+/+} \mathrm{Mucl}^{-/-} \mathrm{BM}-\mathrm{DC}$ took up FITC-dextran from their extracellular environment and in the panels shown (fig. 3c for wild-type DC, fig. 3d for knockout DC), FITCdextran uptake after $60 \mathrm{~min}$ following exposure of DC to this material is clearly shown. For comparison, BM-DC that have not taken up FITC-dextran are also shown (red

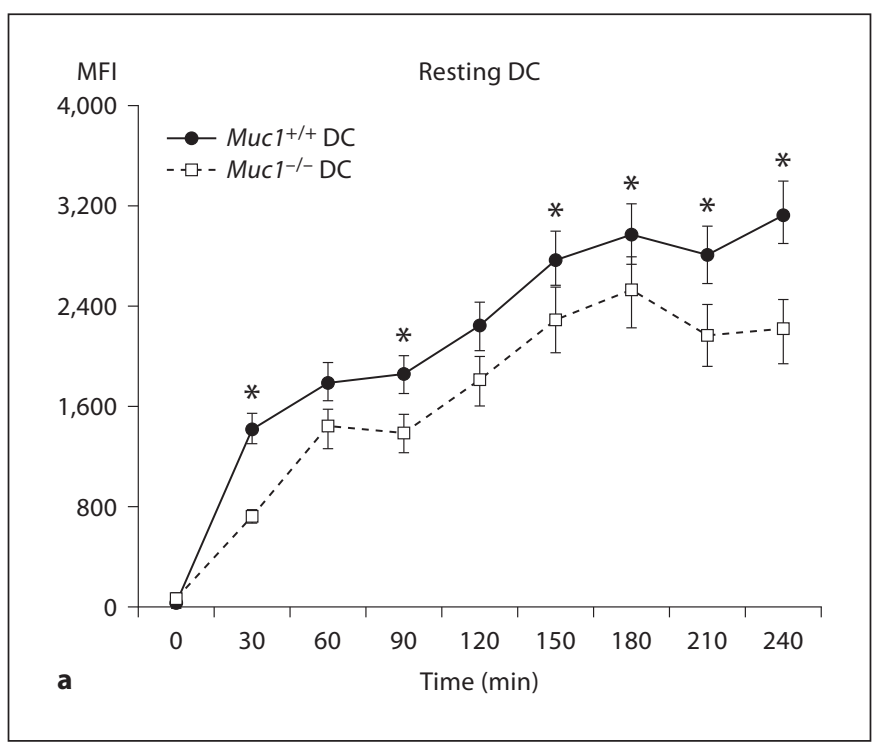

Fig. 2. Time-dependent uptake of FITC-conjugated dextran (molecular weight $40 \mathrm{kDa}$ ) by $\mathrm{Mucl}^{+/+}$and $\mathrm{Mucl}^{-1-}$ DC generated in vitro from bone-marrow precursors. The uptake of FITC-dextran was assessed in resting DC (a) and on activation by LPS (b) or flagellin (c). Note that in $\mathrm{Mucl}^{-/-} \mathrm{DC}$, the uptake of FITC-dextran was significantly less over time than with $\mathrm{Mucl}^{+/+} \mathrm{DC}(\mathrm{p}<0.05)$. In addition, there was evidence of a dampening of the ability of LPS or flagellin-stimulated $\mathrm{Mucl}^{+/+}$and $\mathrm{Mucl}^{-/-}$DC to take up exogenous FITC-dextran, but this was not statistically significant by multiple ANOVA. Data are expressed as geometric mean fluorescence intensity $(\mathrm{MFI}) \pm 1$ standard deviation about the mean ( $\mathrm{n}=3$ independent experiments). rectangular gate, fig. 3c, d). A summary of the data employing this technique is also shown (fig. 3e) and describes the percent internalized FITC-dextran by $\mathrm{Mucl}^{+/+}$as compared with $\mathrm{Mucl}^{-{ }^{-}} \mathrm{BM}-\mathrm{DC}$ at $\mathrm{t}=0, \mathrm{t}=30$ and $\mathrm{t}=60 \mathrm{~min}$ after exposure of DC to FITC-dextran. For comparison, the percent internalized FITC-dextran of BM-DC held at $4^{\circ} \mathrm{C}$ and analyzed under identical conditions is also shown (fig. 3e). As can be seen, BM-DC analyzed for FITC-dextran uptake at $37^{\circ} \mathrm{C}$ show $8-10$ times greater internalized fluorescence than their control counterparts held at $4^{\circ} \mathrm{C}$. Thus, using 2 distinct approaches we concluded that FITC-dextran endocytosis, a receptor-mediated event in DC, is unexpectedly attenuated in the absence of Mucl.
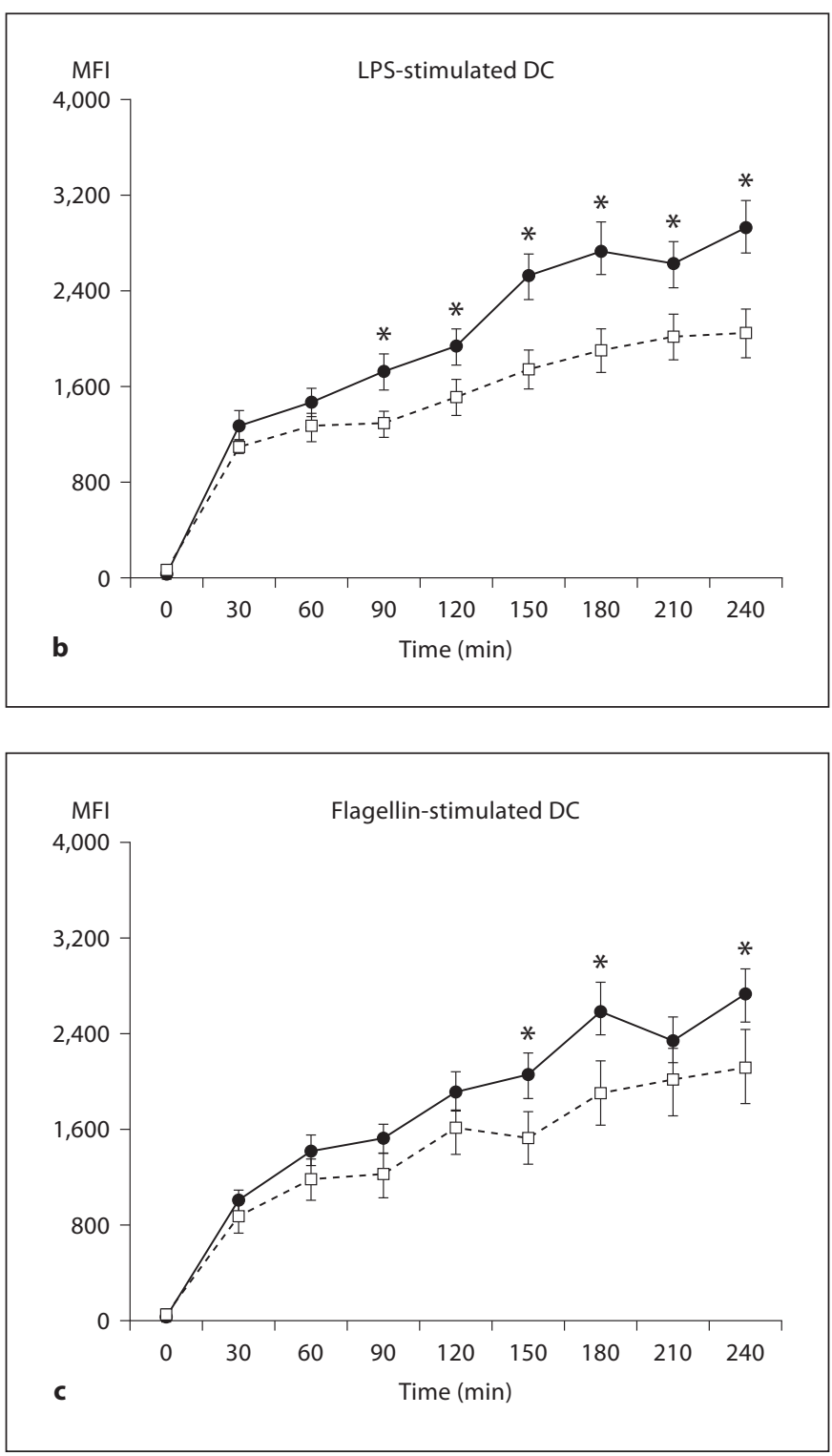

Williams/Bauer/Lu/Guo/Walter/ Bushnell/Lillehoj/Georas 
$\mathrm{Mucl}^{-/-}$DC Exhibit Heightened Co-Stimulatory

Molecule Expression

In addition to displaying processed antigen peptides in the context of MHC, activated DC up-regulate the expression of co-stimulatory molecules that provide the essential second signal for $\mathrm{T}$ cell activation. Using immunofluorescence and flow cytometry, we found that the constitutive expression of CD40, CD80 and CD86 was significantly elevated on $\mathrm{Mucl}^{-1-} \mathrm{BM}-\mathrm{DC}$ as compared with their wild-type counterparts ( $\mathrm{p}<0.01$; fig. $4 \mathrm{a}-\mathrm{c})$. The expression of CD40, CD80 and CD86 was further enhanced on $\mathrm{Mucl}^{+/+}$DC in response to LPS or flagellin, consistent with a maturing phenotype (fig. 4a, c). In con- trast, only CD40 and CD80 were significantly increased on $\mathrm{Mucl}^{-/-}$DC in response to LPS (fig. 4b, c), and although there were trends towards increased expression of CD86 in response to LPS stimulation, these differences were not statistically significant. Interestingly, $\mathrm{Mucl}^{-/-} \mathrm{DC}$ also failed to show enhanced expression of any of the 3 costimulatory molecules examined after stimulation with flagellin (fig. 4b, c). This was in sharp contrast to flagellin-stimulated wild-type DC, which up-regulated CD40, CD80 and CD86 compared to resting cells (fig. 4a, c). One possible explanation for these data is that DCs depend in part on intact expression of Mucl for enhanced expression of co-stimulatory molecules in response to flagellin.

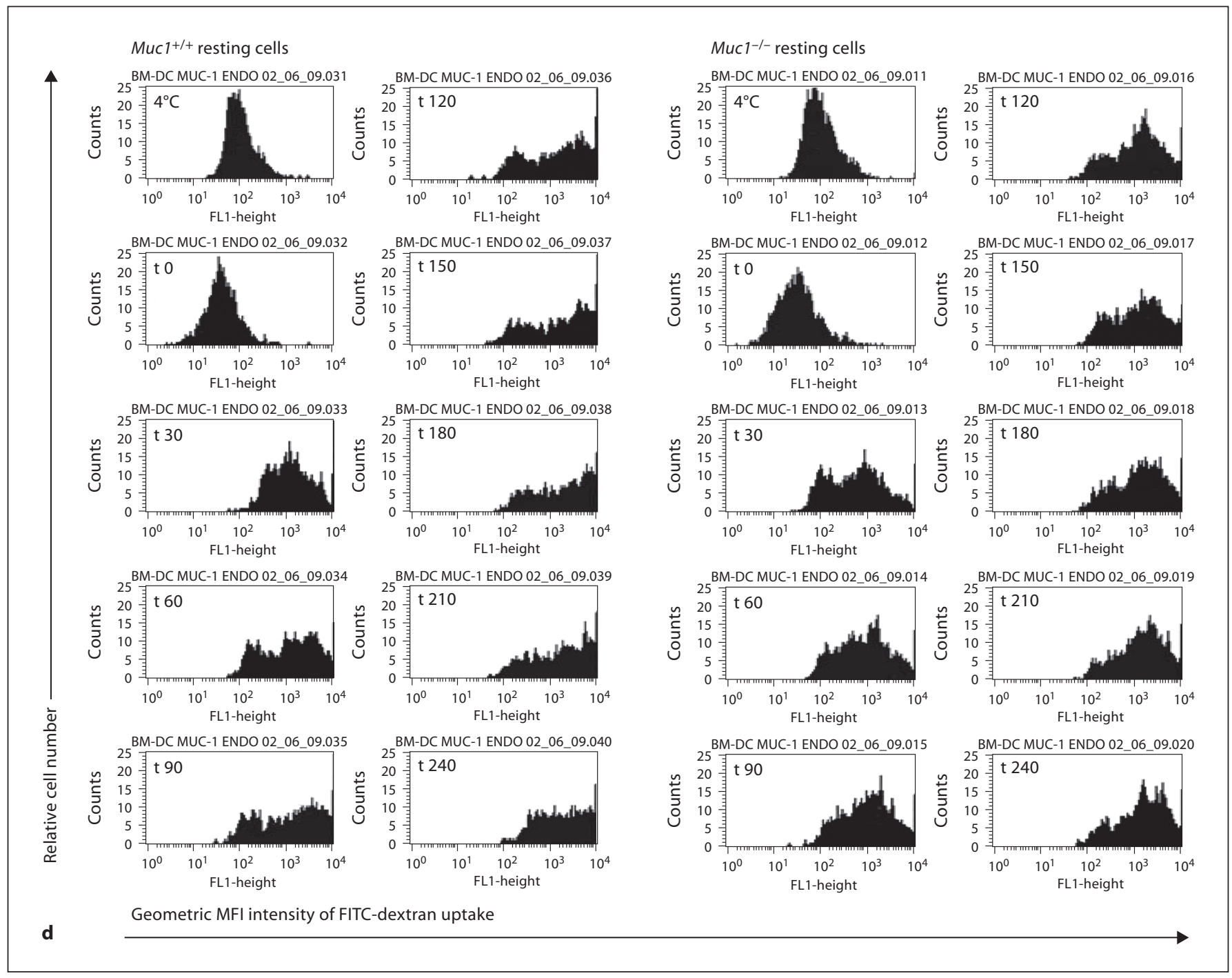

Fig. 2. A series of flow histograms of FITC-dextran uptake of immature BM-DC from $\mathrm{Mucl}^{+/+}$and $\mathrm{Mucl}^{-/-}$mice from a typical experiment is also shown for the whole time course of the experiment (d). 

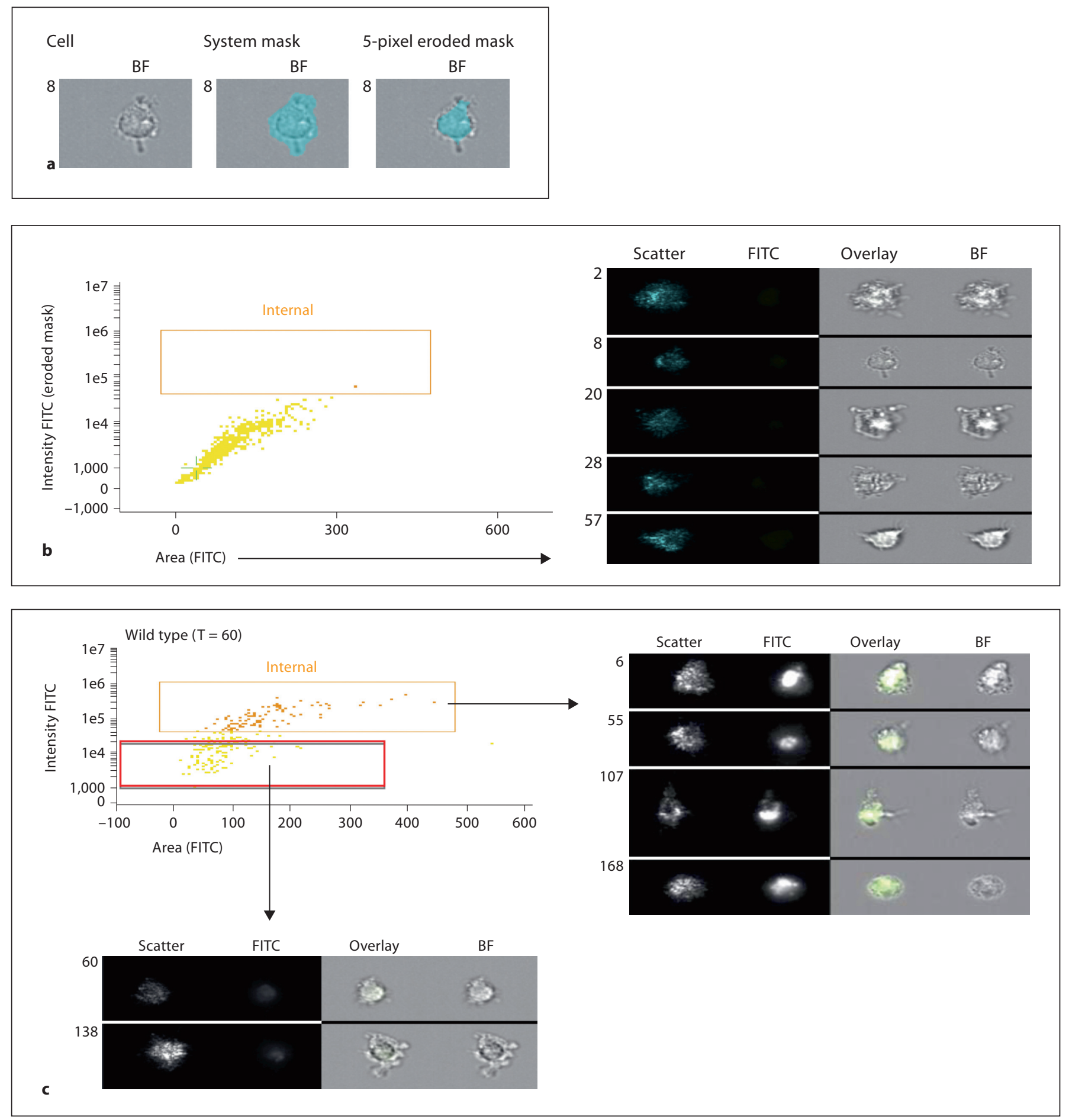

Fig. 3. Validation of the time-dependent internalization of FITCdextran by ImageStream cytoflourographic analysis of $\mathrm{Mucl}^{+/+}$ and $\mathrm{MuCl}^{-/-}$DC. In experiments of FITC-dextran uptake by endocytic and phagocytic mechanism described above, aliquots were also studied for cytoplasmic uptake and accumulation of FITC-dextran, as opposed to membrane-bound antigen. Using ImageStream imaging flow cytometric analyses, intracellular uptake of FITC-dextran by DC was confirmed. Representative bright field images (a) show a DC as well as the system mask and 5-pixel eroded mask are shown. A representative dot plot and fluorescence imagery is also shown (b) from a $t=0 \mathrm{~min}$ control sample. These panels show that there is very little if any FITC signal that can be detected in these cells, or any cells at $\mathrm{t}=0 \mathrm{~min}$, as one would expect. The images on the right in $\mathbf{b}$ show the range of cell sizes and shapes observed by the ImageStream. 
In order to ensure that the BM-DC used in these experiments faithfully represented DC in situ, we next isolated highly pure primary lung (fig. $5 \mathrm{a}-\mathrm{c}$ ) and splenic (fig. 6a, b) DC from $\mathrm{Mucl}^{-/-} \mathrm{DC}$ and $\mathrm{Mucl}^{+/+}$mice. In these experiments, we studied expression of the costimulatory molecules CD40, CD54 and CD86, and found that in contrast to BM-DC, the expression of CD40 by lung DC was similar between genotypes in the resting state and after LPS stimulation (fig. 5). However, $\mathrm{MuCl}^{-/-}$lung DC displayed enhanced expression of CD40 on activation by flagellin while their wild-type counterparts did not respond under these conditions ( $p<0.05$; fig. 5b). We also found that CD86 expression by lung DC was similar between genotypes and did not change on either $\mathrm{Mucl}^{-/-}$or $\mathrm{Mucl}^{+/+}$lung DC after stimulation by either LPS or flagellin (fig. 5). By contrast, expression of CD54 was markedly greater on lung $\mathrm{Mucl}^{-/}$ DC as compared to their wild-type counterparts both before and after stimulation with LPS or flagellin. Both $\mathrm{MuCl}^{-/-}$and $\mathrm{Mucl}^{+/+}$lung DC exhibited marginal but statistically significant enhanced expression of CD54 on activation by LPS and flagellin ( $\mathrm{p}<0.05$; fig. 5 ).

We also observed that expression of CD40 by $\mathrm{Mucl}^{-1-}$ and $\mathrm{MuCl}^{+/+}$splenic DC was similar and only partially enhanced on activation by LPS ( $p<0.05$; fig. 6). Additionally, while the expression of CD86 was also similar be-

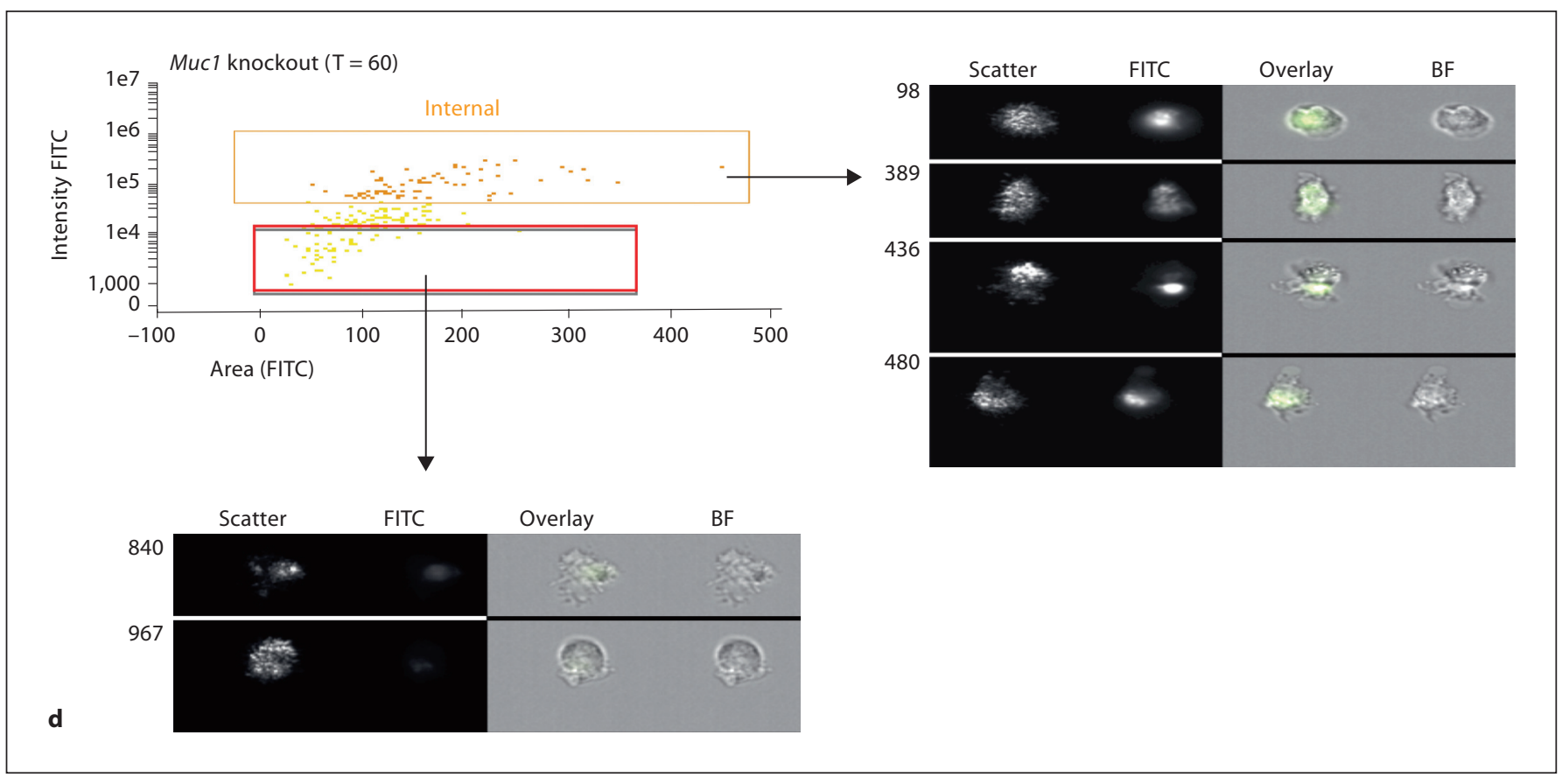

Fig. 3. Representative data from $\mathrm{Mucl}^{+/+} \mathrm{DC}$ is shown (c) as well as from $\mathrm{Mucl}^{-/-} \mathrm{DC}$ (d) sampled $60 \mathrm{~min}$ after pulsing DC with FITC-dextran. Also included are representative images, with the overlay showing the FITC signal (green) clearly inside the cell (right panel of $\mathbf{c}$ and $\mathbf{d}$ ). For comparison, the cells not showing internalization (the red rectangular gate) are shown below each figure $(\mathbf{c}, \mathbf{d})$. Mean data from 2 independent experiments show a measurable effect of dampened FITC-dextran uptake by $\mathrm{Mucl}^{-/-}$ DC as compared with their wild-type counterparts at $\mathrm{t}=30 \mathrm{~min}$ and $\mathrm{t}=60 \mathrm{~min}(\mathbf{e})$, thus confirming the standard flow cytometric measures of figure 2. Additionally, stimulating cells with flagellin had little effect on the uptake of FITC particles using DC from either genotype (e).

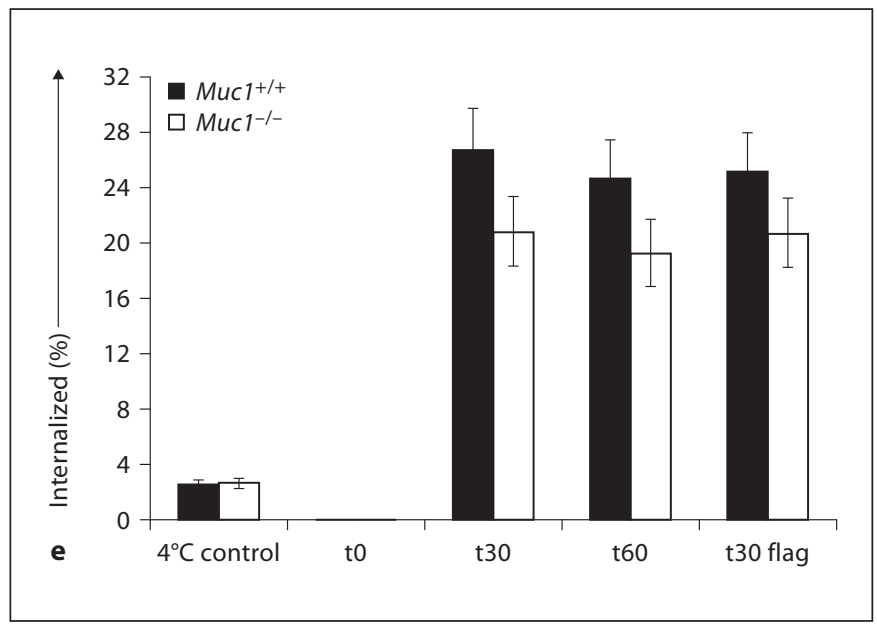


tween genotypes, LPS enhanced expression of CD86 in both $\mathrm{Mucl}^{-/-}$and $\mathrm{Mucl}^{+/+}$splenic DC $(\mathrm{p}<0.05)$, while only $\mathrm{Mucl}^{-/-} \mathrm{DC}$ responded to flagellin, further supporting our hypothesis of enhanced sensitivity to exogenous activation of $\mathrm{MuCl}^{-/-}$DC by this TLR 5 agonist ( $\mathrm{p}<0.05$; fig. 5b). Although the expression of CD40 and CD86 was similar on splenic DC from both genotypes, the expression of CD54 was markedly greater on splenic $\mathrm{Mucl}^{-/-} \mathrm{DC}$ than their wild-type counterparts both in the resting state and following stimulation (fig. 6). However, both $\mathrm{Mucl}^{-/-}$ and their wild-type counterparts exhibited enhanced expression of CD54 on activation by LPS or flagellin.

\section{Activation of $\mathrm{Mucl}^{-/-}$DC by Flagellin Magnifies \\ Pro-Inflammatory Cytokine Production}

When examining cytokine secretion, we found that deletion of $\mathrm{Mucl}^{-1-}$ in BM-DC promoted an unusual pattern of constitutive cytokine secretion as well as altered responsiveness upon activation by LPS or flagellin (fig. 7a-d). Constitutive secretion of IL-12p40 by either $\mathrm{Mucl}^{+/+}$or $\mathrm{Mucl}^{-/-}$BM-DC was very low. However, secretion of IL-12p40 by $\mathrm{Mucl}^{-/-}$DC was markedly enhanced on activation of both $\mathrm{Mucl}^{-/-}$and $\mathrm{Mucl}^{+/+} \mathrm{DC}(\mathrm{p}<0.01$; fig. 7a). Interestingly, on activation by flagellin, $\mathrm{Mucl}^{-/-}$ BM-DC secreted far greater levels of IL-12p40 than their wild-type counterparts in several independent experi-

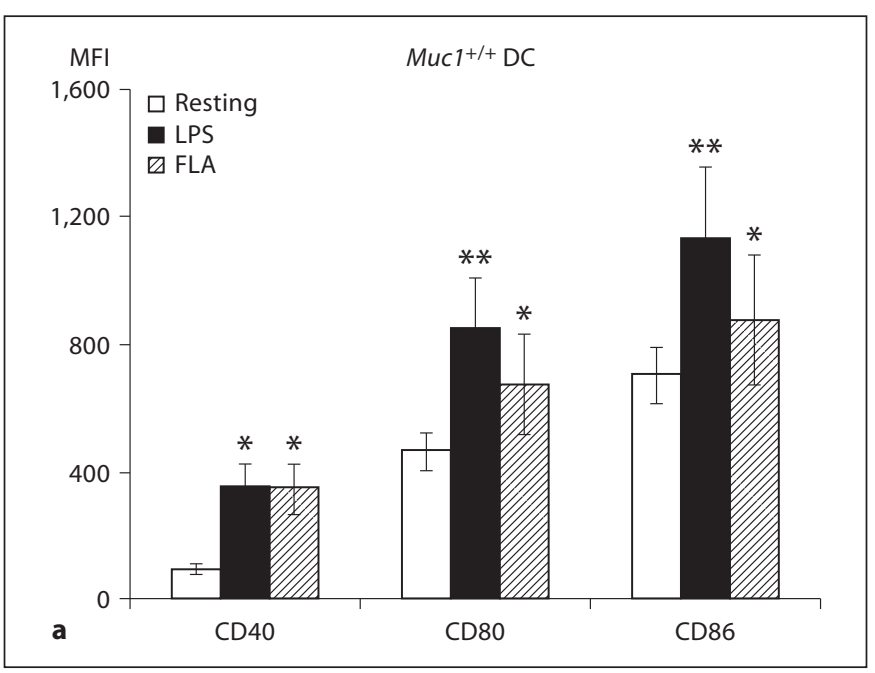

Fig. 4. Cell surface-expression of co-stimulatory molecules in $\mathrm{MuCl}^{+/+}$and $\mathrm{Mucl}^{-/-}$BM-DC as quantified by multi-parameter flow cytometry. Data are expressed (in $\mathbf{a}$ and $\mathbf{b}$ ) as geometric mean fluorescence intensity $(\mathrm{MFI}) \pm 1$ standard deviation about the mean ( $\mathrm{n}=6$ independent experiments of 3 or 4 mice per group). The constitutive expression levels of CD40, CD80 and ments (fig. 7a). Under these circumstances, $\mathrm{Mucl}^{-1-} \mathrm{DC}$ secreted $\sim 2.5$-fold more IL-12p40 than their wild-type counterparts in response to flagellin ( $p<0.01$; fig. 7a). We observed a very similar pattern when assessing the secretion of TNF- $\alpha$ by $\mathrm{Mucl}^{-/-}$as compared with $\mathrm{Mucl}^{+/+}$ DC (fig. 7b). $\mathrm{Mucl}^{-/-}$DC secreted far greater levels of TNF- $\alpha$ on activation by flagellin as compared with their wild-type counterparts (fig. 7b), while the levels secreted by LPS stimulated $\mathrm{Mucl}^{-/-}$and $\mathrm{Mucl}^{+/+}$DC were highly comparable (fig. 7b). In contrast, whereas both LPS and flagellin increased IL-10 secretion in $\mathrm{Mucl}^{+/+} \mathrm{DC}$ (fig. 7c), only LPS modestly enhanced IL-10 production in $\mathrm{Mucl}^{-/-}$ DC but at levels that were at least half of those produced by there wild-type counterparts (fig. $7 c, p<0.05$ ). Moreover, while flagellin provoked enhanced secretion of IL10 by $\mathrm{Mucl}^{+/+} \mathrm{DC}$, it failed to stimulate enhanced release of IL-10 by $\mathrm{Mucl}^{-1-}$ BM-DC counterparts (fig. 7c).

We also studied secretion of the chemokine KC (or CXCL1) by DC and determined that under resting conditions the spontaneous secretion of $\mathrm{KC}$ was similar for $\mathrm{Mucl}^{-/-}$and $\mathrm{Mucl}^{+/+} \mathrm{DC}$ and that the magnitude of enhanced secretion of $\mathrm{KC}$ was similar between genotypes on activation by LPS ( $p<0.01$; fig. $7 d$ ). By contrast, $\mathrm{Mucl}^{-/-}$BM-DC exhibited significantly enhanced production of $\mathrm{KC}$ as compared their wild-type counterparts on activation by flagellin ( $\mathrm{p}<0.05$; fig. $7 \mathrm{~d})$.

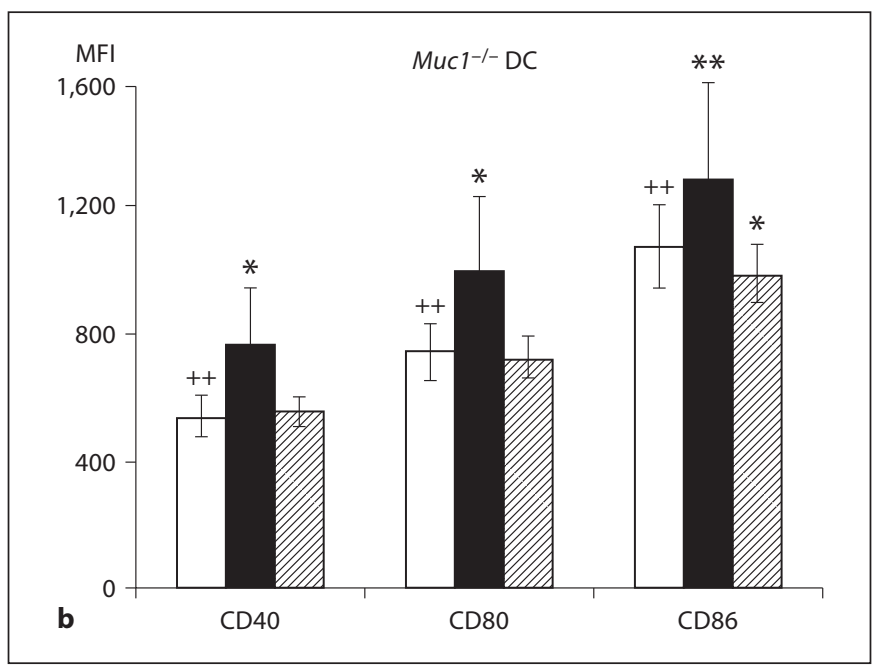

CD86 were significantly greater on $\mathrm{Mucl}^{-/-} \mathrm{DC}$ as compared with their $\mathrm{MuCl}^{+/+} \mathrm{DC}$ counterparts $(\mathrm{p}<0.01)$, suggesting a more mature phenotype of Mucl-disrupted DC. ${ }^{*} \mathrm{p}<0.05 ;{ }^{* *} \mathrm{p}<0.01$ or $\mathrm{p}<0.001{ }^{++} \mathrm{p}<0.01$, all wild-type vs. knockout DC. FLA = Flagellin stimulated. Data represent geometric MFI of the described data. 
A striking finding was that $M u c 1^{-/-}$DC secreted constitutively greater levels of the pleiotropic cy tokine VEGF than $\mathrm{Mucl}^{+/+}$DC $(\mathrm{p}<0.01)$. VEGF secretion was further increased in $\mathrm{Mucl}^{-1-}$ DC in response to both LPS and flagellin, whereas only LPS significantly increased VEGF secretion by $\mathrm{Mucl}^{+/+} \mathrm{DC}(\mathrm{p}<0.05)$. Additionally,
$\mathrm{Mucl}^{-1-} \mathrm{DC}$ also secreted constitutively greater levels of the cytokine IL- 6 than $\mathrm{Mucl}^{+/+} \mathrm{DC}(\mathrm{p}<0.05)$. IL- 6 secretion was further increased in $\mathrm{Mucl}^{-/-} \mathrm{DC}$ and $\mathrm{Mucl}^{+/+}$ DC in response to both LPS and flagellin, although the levels secreted by $\mathrm{Mucl}^{-1-} \mathrm{DC}$ were again greater than their wild-type BM-DC counterparts $(\mathrm{p}<0.05)$.

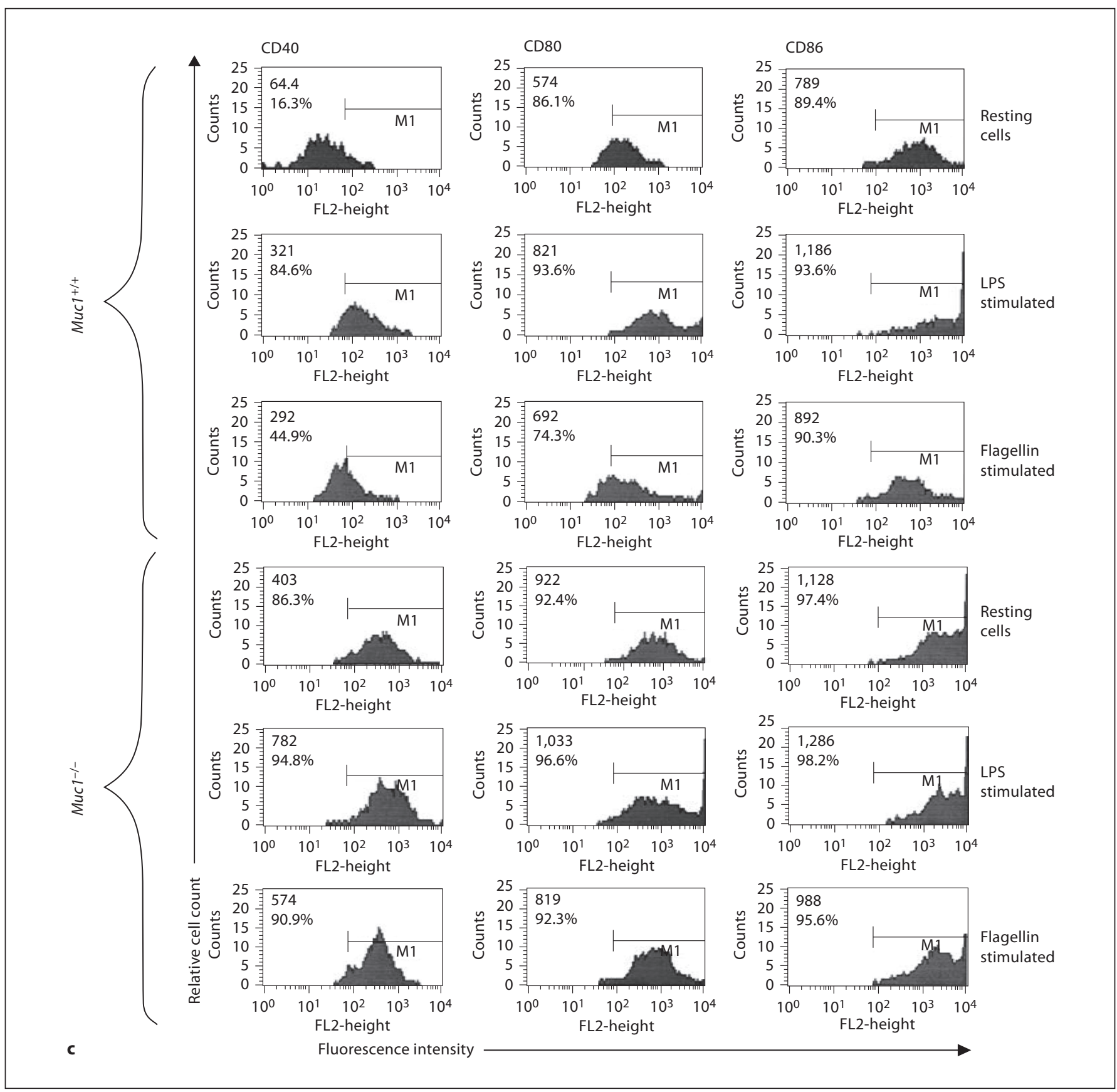

Fig. 4. c Typical sets of flow cytometric histograms of the data described in figure 3a. Data represent geometric mean fluorescence intensity (MFI) and percent (\%) of cells positive of the described data. 

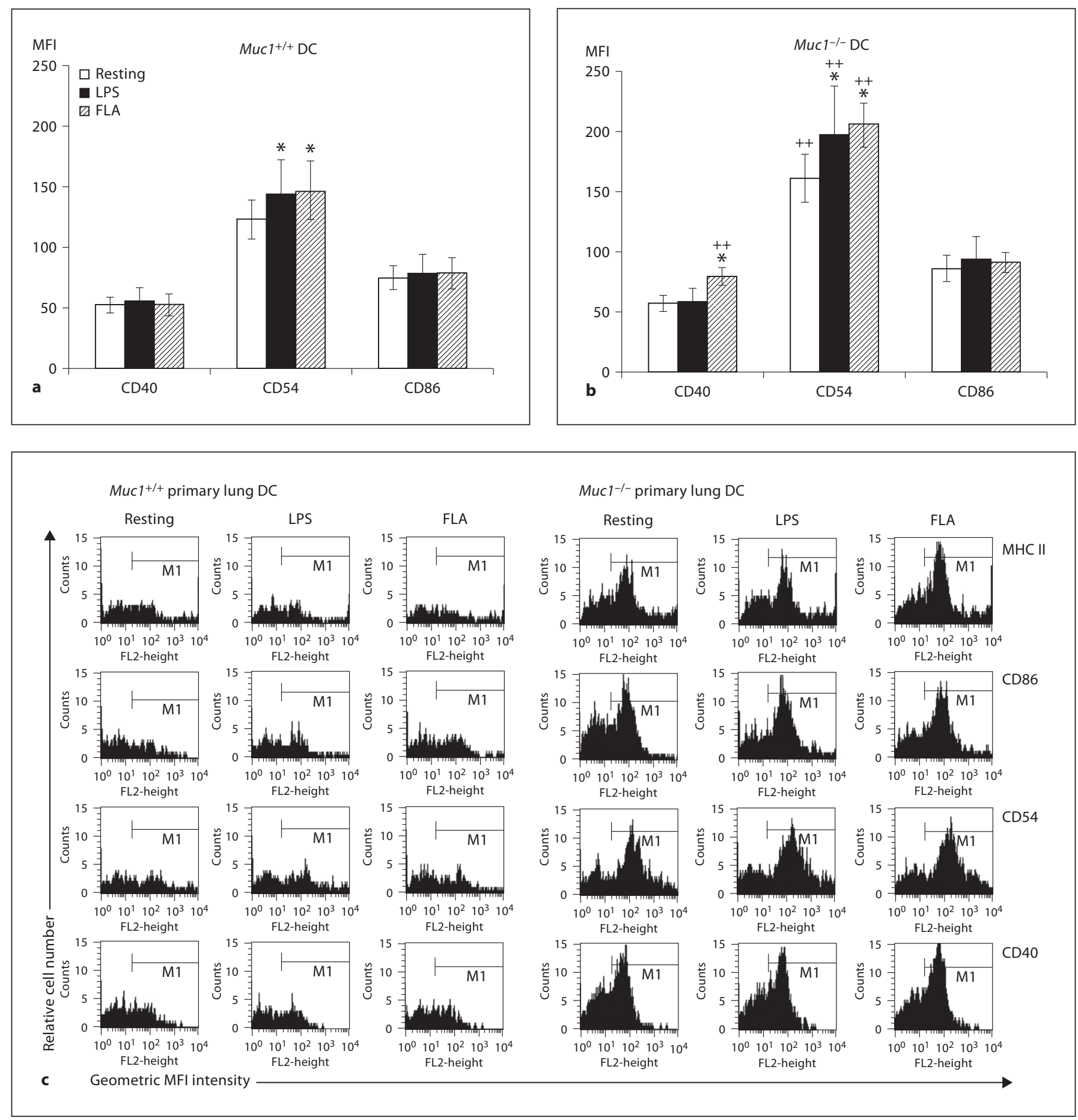

Fig. 5. Cell surface-expression of co-stimulatory molecules CD40, CD54 (ICAM-1) and CD86 by $\mathrm{Mucl}^{+/+}$and $\mathrm{Mucl}^{-/-}$primary lung DC as quantified by multi-parameter flow cytometry. Data are expressed (in $\mathbf{a}$ and $\mathbf{b}$ ) as geometric mean fluorescence intensity $(\mathrm{MFI}) \pm 1$ standard deviation about the mean $(\mathrm{n}=3$ independent experiments of 6 mice per group). ${ }^{*} \mathrm{p}<0.05$; ${ }^{* *} \mathrm{p}<0.01$ or $\mathrm{p}<$ $0.001 ;{ }^{++} \mathrm{p}<0.01$, all wild-type vs. knockout DC. $\mathbf{c}$ Typical sets of flow cytometric histograms of the data described in $\mathbf{a}$ and $\mathbf{b}$ as well as expression of cell surface MHC class II. FLA = Flagellin stimulated. 


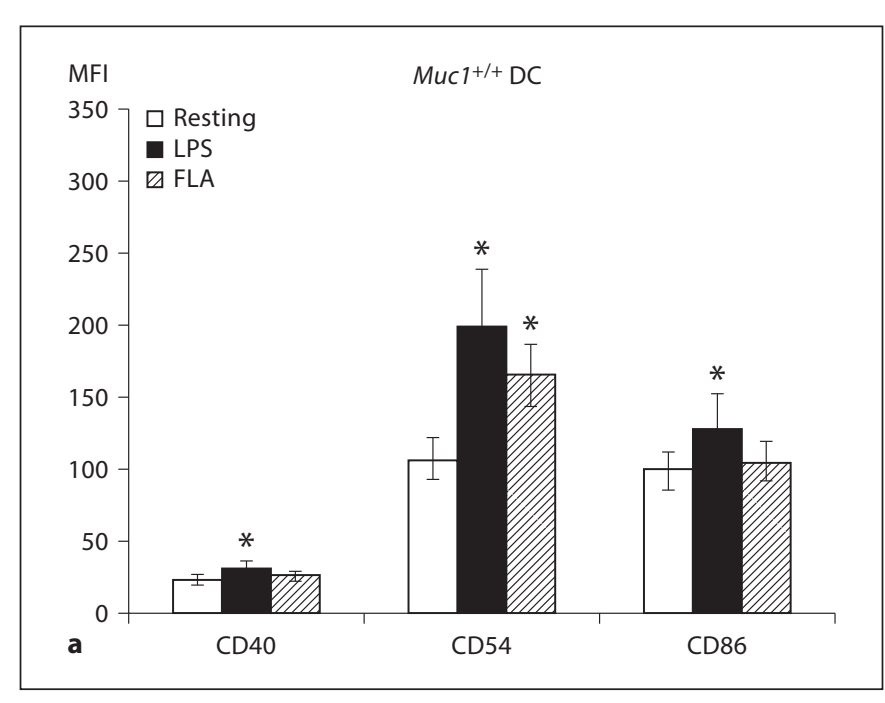

Fig. 6. Cell surface-expression of co-stimulatory molecules CD40, CD54 (ICAM-1) and CD86 by $\mathrm{Mucl}^{+/+}$and $\mathrm{Mucl}^{-/-}$primary splenic DC as quantified by multi-parameter flow cytometry. Data are expressed (in $\mathbf{a}$ and $\mathbf{b}$ ) as geometric mean fluorescence

\section{Activation of Lung or Splenic DC and Differential}

\section{Pro-Inflammatory Cytokine Secretion}

Next, we investigated cytokine secretion using primary lung (fig. 8a-d) or splenic (data not shown) DC from both genotypes. Since in vitro propagated BM-DC displayed hyper-responsiveness to in vitro stimulation by LPS and/or flagellin, we wanted to establish to what extent these important observations would be reproduced by primary DC freshly isolated from lung and spleen of $\mathrm{Mucl}^{-/-}$and $\mathrm{Mucl}^{+/+}$mice.

We found that many of our observations established with BM-DC were reproduced in DC purified from lung and spleen, and in many examples, $\mathrm{Mucl}^{-/-} \mathrm{DC}$ isolated from these organs were found to be even more sensitive to ex vivo stimulation with LPS or flagellin. For example, we found that lung $\mathrm{MuCl}^{-/-} \mathrm{DC}$ constitutively secreted greater levels of IL-12p40 than their wild-type counterparts both at baseline and following LPS and flagellin exposure ( $p<0.05$; fig. 8a). Similar observations were made for the secretion of TNF- $\alpha$ (fig. 8 b) by lung DC, although we could not detect significant levels of constitutive secretion by either $\mathrm{Mucl}^{-/-}$and $\mathrm{Mucl}^{+/+}$lung DC (fig. 8b).

When considering secretion of IL-10 (fig. 8c), there was little constitutive IL-10 secretion whereas both LPS and flagellin enhanced secretion of IL-10 by wild-type $\mathrm{Mucl}^{+/+}$DC more than $\mathrm{Mucl}^{-/-} \mathrm{DC}(\mathrm{p}<0.05$; fig. 8c), similar to the case of bone marrow-derived DC (fig. 7c). Finally, both $\mathrm{Mucl}^{-/-}$and $\mathrm{Mucl}^{+/+}$lung DC secreted sim-

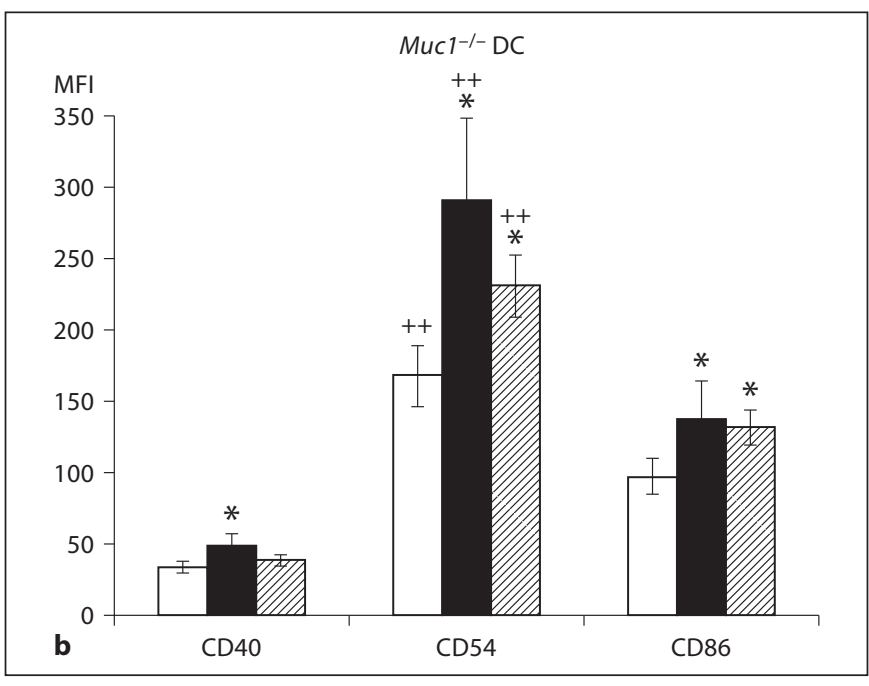

intensity (MFI) \pm 1 standard deviation about the mean $(\mathrm{n}=3$ independent experiments of 6 mice per group). ${ }^{*} \mathrm{p}<0.05 ;{ }^{*} \mathrm{p}<$ 0.01 or $\mathrm{p}<0.001 ;^{++} \mathrm{p}<0.01$, all wild-type vs. knockout DC. LPS $=$ Lipopolysaccharide stimulated; FLA = flagellin stimulated.

ilarly low levels of the chemokine KC/CXCL1 that could be markedly enhanced on activation by LPS or flagellin ( $\mathrm{p}<0.01$; fig. $8 \mathrm{~d}$ ). Concordant with our observations of IL-12p40 and TNF secretion by lung DC, LPS- or flagellin-stimulated $\mathrm{Mucl}^{-1-} \mathrm{DC}$ tended to secrete greater levels of $\mathrm{KC}$ than their $\mathrm{Mucl}^{+/+} \mathrm{DC}$ counterparts (fig. 8d).

We observed very similar responses using primary spleen DC isolated from wild-type and $\mathrm{Mucl}^{-/-}$mice (data not shown). For example, similar to primary lung DC, spleen DC from $\mathrm{Mucl}^{+/+}$mice secreted significantly more IL-12p40, and TNF, but less IL-10 than DC from $\mathrm{Mucl}^{-1-}$ mice after activation with LPS and/or flagellin (not shown). Finally, concordant with the observations for lung DC, we found that $\mathrm{Mucl}^{-1-}$ splenic DC secreted more $\mathrm{KC}$ on activation by LPS or flagellin as compared their $\mathrm{Mucl}^{+/+}$DC counterparts (not shown, $\mathrm{p}<0.01$ ). Although there were some stimulus-specific differences in cytokine secretion when comparing BM-DC with primary lung or spleen DC (fig. 7, 8), taken together these data strongly support the idea that Mucl normally dampens pro-inflammatory cytokine secretion in DC in response to different TLR ligands (see also Discussion).

\section{$\mathrm{Mucl}^{-/-}$DC Constitutively Drive Greater Naive CD4+}

$T$ Cell Proliferation and Altered T Cell Responsiveness

One of the most important functions of DC is to migrate to the draining regional lymph nodes and form stimulatory synapses with naive CD4+ T cells. DC-medi- 

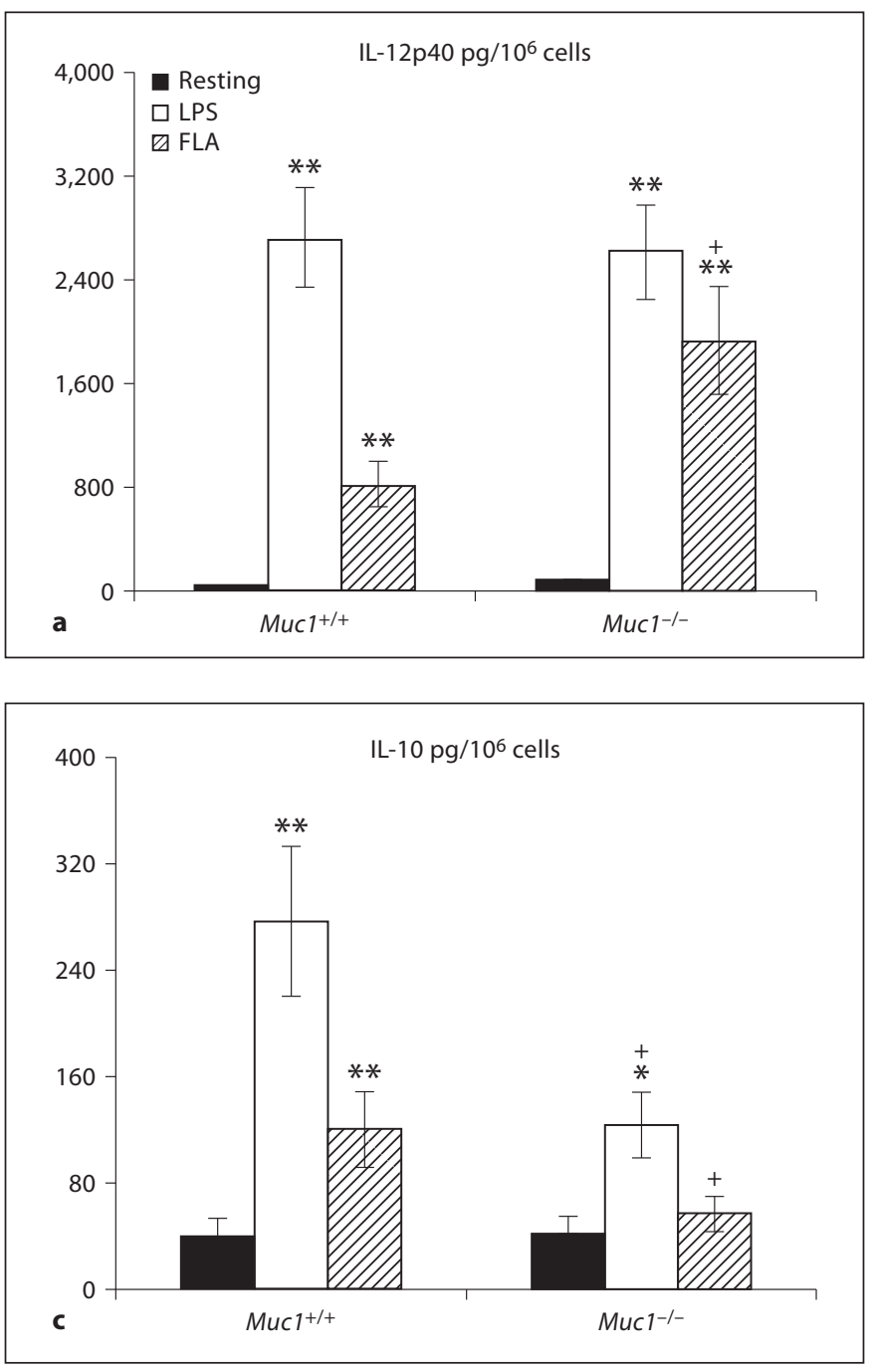

Fig. 7. Secretion of inflammatory cytokine production by $\mathrm{Mucl}^{+/+}$ and $\mathrm{Mucl}^{-/-}$BM-DC (see Materials and Methods). Data are described as pg of cytokine secreted per million DC (pg/106 cells) \pm 1 standard deviation about the mean $(n=5-9$ independent ex-

ated activation of $\mathrm{T}$ cell activation can be estimated in vitro by titrating variable numbers of DC against a constant number of CD4+ T cells and measuring cell cycle progression and cytokine production. In order to examine the effects of Mucl deficiency on the ability of DC to stimulate $\mathrm{T}$ cells, we titrated 5 -fold dilutions of resting or flagellin-stimulated DC from $\mathrm{Mucl}^{-/-}$mice or their wildtype counterparts with highly pure naive allogeneic responder T cells. After 4 days of co-culture, specific CD4+ $\mathrm{T}$ cell proliferation was quantified by the incorporation of BrdU (see Methods). Consistent with greater expression of costimulatory molecules (fig. 4), we found that
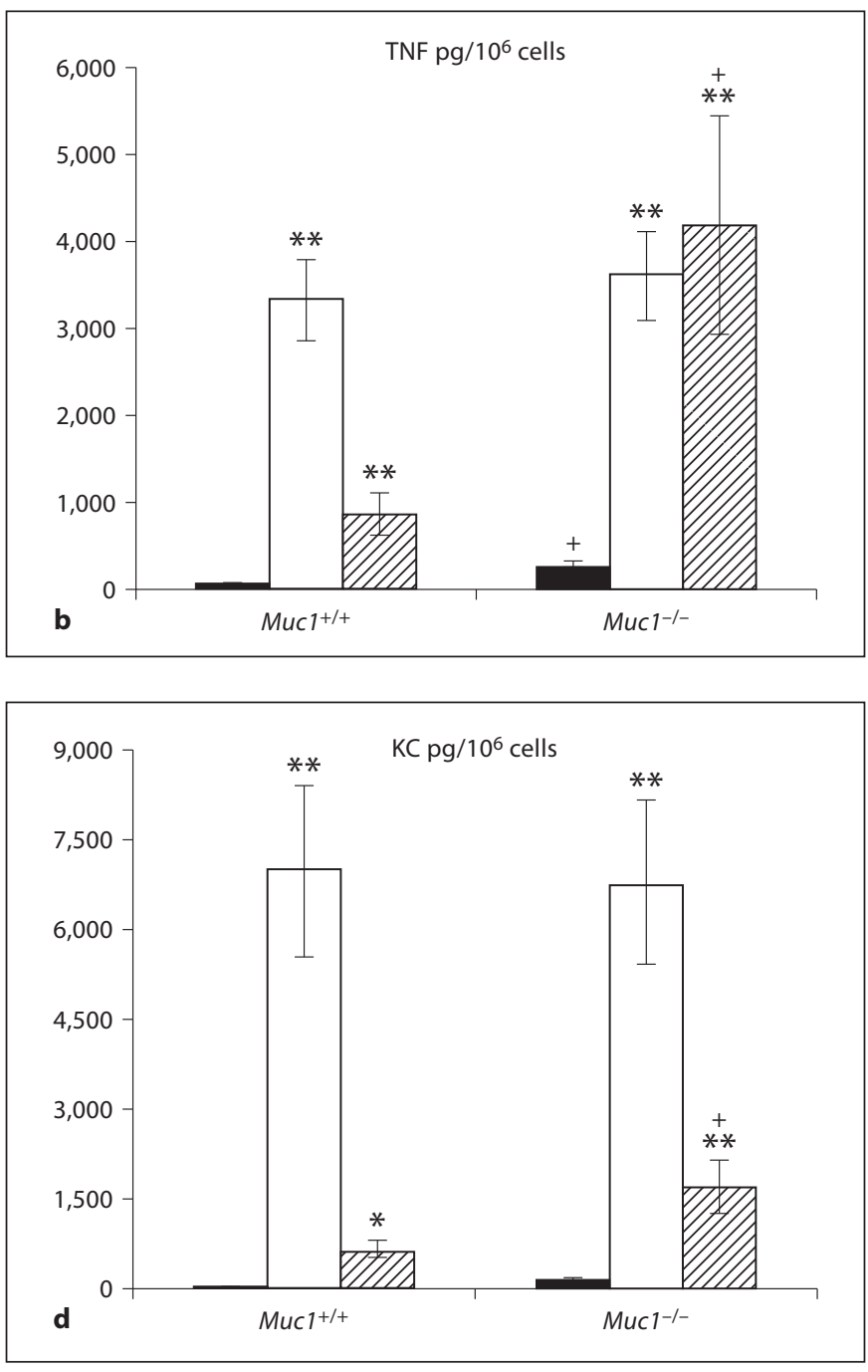

periments). The following cytokines were quantified: IL-12p40 (a), TFN- $\alpha$ (b), IL-10 (c), KC (d). Alpha values: * $\mathrm{p}<0.05$; ${ }^{* *} \mathrm{p}<$ $0.01 ;{ }^{+} \mathrm{p}<0.05$, all wild-type vs. knockout DC. FLA $=$ Flagellin stimulated.

$\mathrm{Mucl}^{-/-}$BM-DC exhibited a constitutive ability to more potently stimulate naive $\mathrm{CD} 4+\mathrm{T}$ cell proliferation than wild-type DC (fig. 9a). Activation of $\mathrm{Mucl}^{+/+} \mathrm{DC}$ with flagellin enhanced $\mathrm{CD} 4+\mathrm{T}$ cell proliferation compared with unstimulated $\mathrm{Mucl}^{+/+} \mathrm{DC}$ (fig. 9b). In contrast, flagellin-exposed $\mathrm{Mucl}^{-/-} \mathrm{DC}$ did not induce greater T cell proliferation than resting $\mathrm{Mucl}^{-1-} \mathrm{DC}$ implicating that such DC were already at a heightened state of CD4+ T cell allo-stimulation.

We also contrasted the stimulatory ability of BM-DC with their lung (fig. 9c, d) and splenic (fig. 9e, f) counterparts. Concordantly, we found that in the resting 

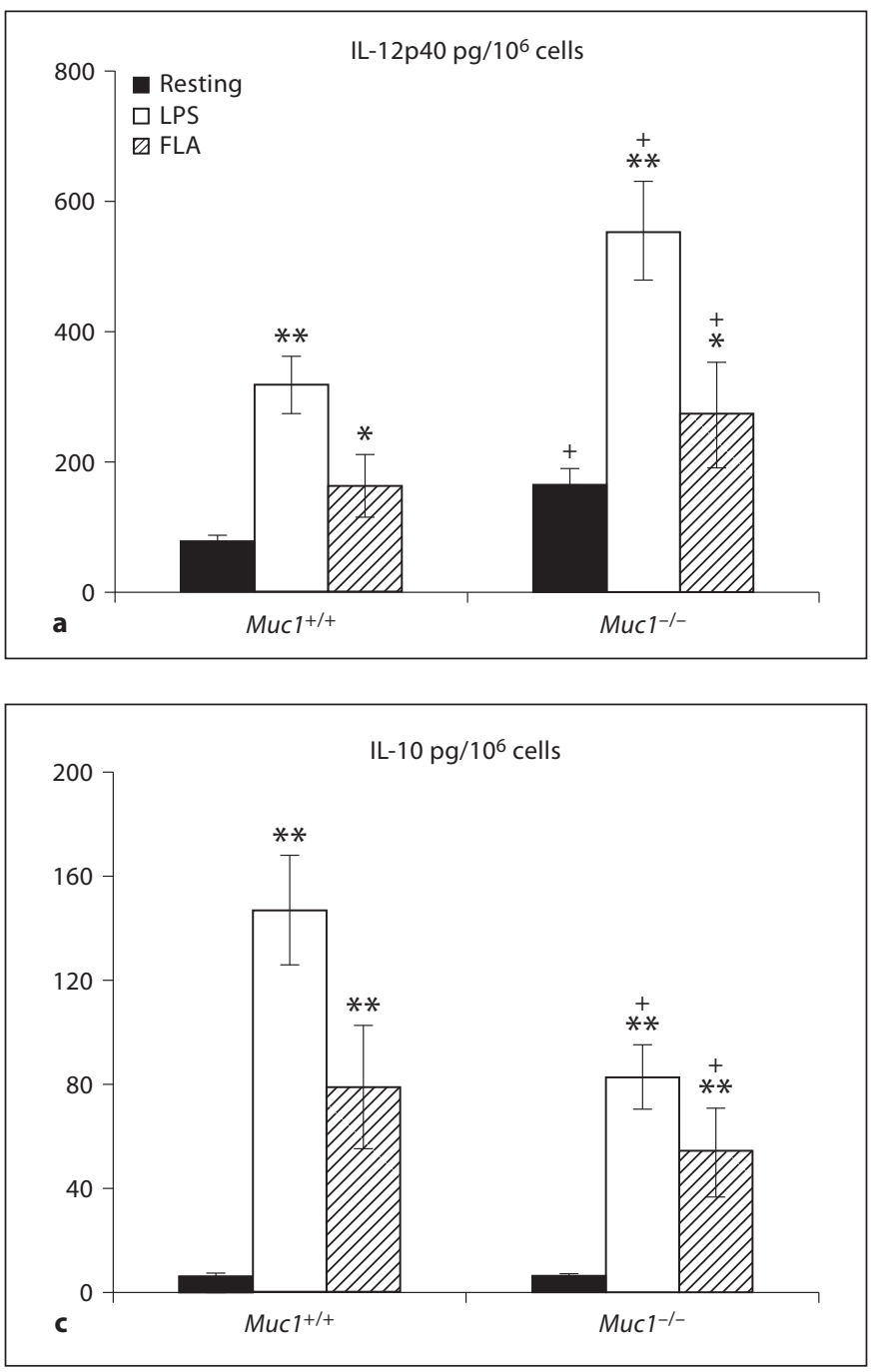

Fig. 8. Secretion of inflammatory cytokine production by $\mathrm{Mucl}^{+/+}$ and $\mathrm{MuCl}^{-/-}$primary lung DC (see Materials and Methods; a-d). Data are described as pg of cytokine secreted per million DC $\left(\mathrm{pg} / 10^{6}\right.$ cells $) \pm 1$ standard deviation about the mean $(\mathrm{n}=3$ inde-

state, both lung and splenic $M u c 1^{-1-}$ DC exhibited a heightened ability to stimulate naive $\mathrm{CD}+\mathrm{T}$ cell proliferation as compared with $\mathrm{Mucl}^{+/+}$lung or splenic DC. In addition, activation of either $\mathrm{Mucl}^{+/+}$lung DC (fig. 9d) or $\mathrm{MuCl}^{+/+}$splenic DC (fig. 9f) with flagellin, enhanced CD4+ T cell proliferation compared with unstimulated $\mathrm{Mucl}^{+/+}$DC (fig. 9c, e, respectively). By contrast however, unlike in vitro propagated BM-DC, flagellin stimulated $\mathrm{Mucl}^{-/-}$lung DC (fig. 9d) and $\mathrm{Mucl}^{-/-}$splenic DC (fig. 9f) indeed showed an increased ability to stimulate $\mathrm{CD} 4+\mathrm{T}$ cell proliferation as compared to unstimulated resting DC.
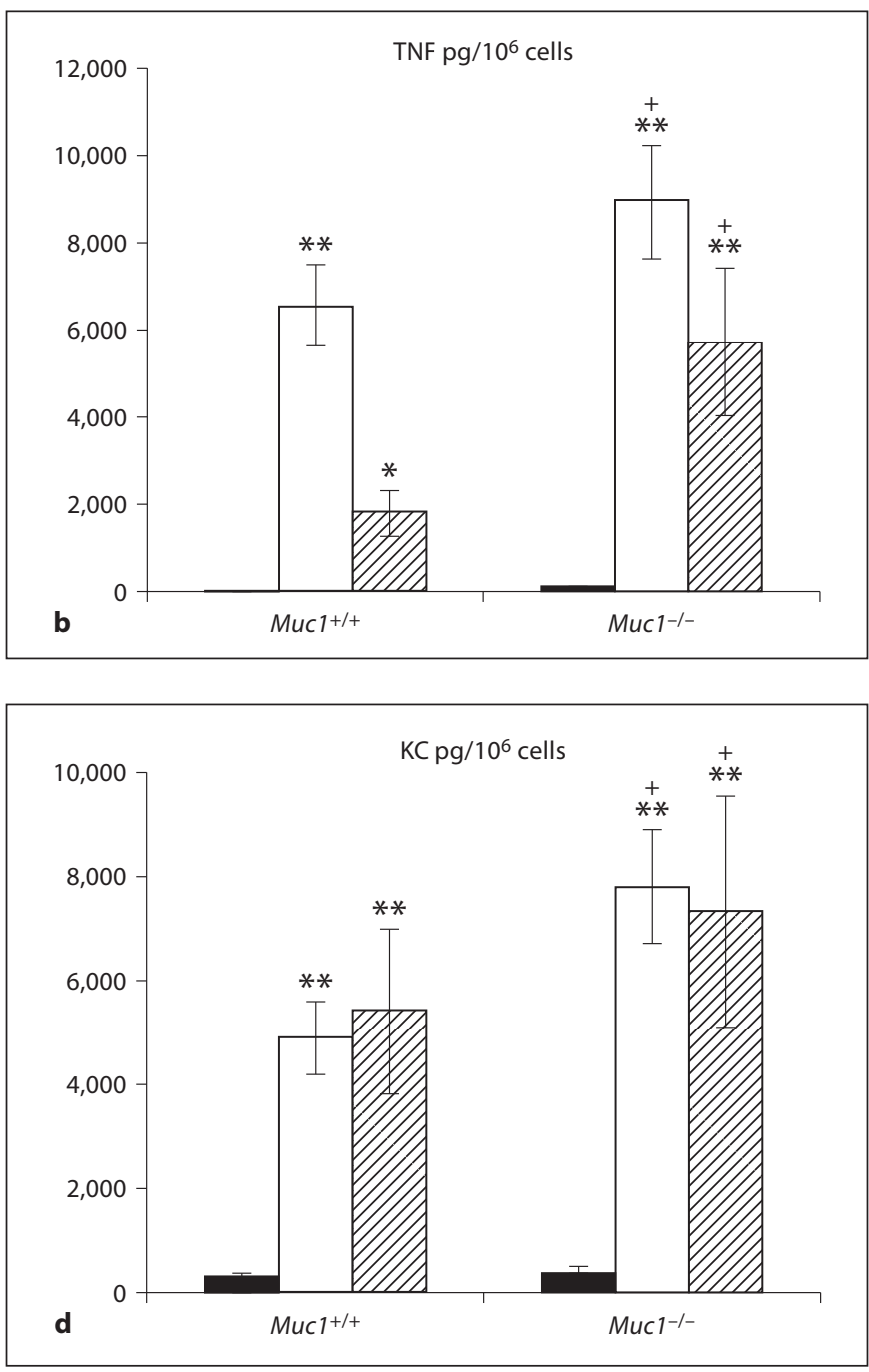

pendent experiments of 6 mice per group). The following cytokines were quantified: IL-12p40 (a), TNF- $\alpha$ (b), IL-10 (c), KC production (d). ${ }^{*} \mathrm{p}<0.05 ;{ }^{*} \mathrm{p}<0.01 ;{ }^{+} \mathrm{p}<0.05$, all wild-type vs. knockout DC. FLA = Flagellin stimulated.

By also measuring the secretion of both DC- and T cell-derived cytokines (e.g. IL-12p40 vs. IFN- $\gamma$ and IL-13, respectively) by multiplex cytokine array assays (Bioplex; Bio-Rad) in co-cultures of DC with naive CD4+ T cells, we determined whether Mucl deficiency altered cytokine secretion during DC-T cell cross-talk (fig. 10a-d). We note that these assays were performed after extensive washing of TLR ligand-exposed DC, and thus reflect indirect effects of DC maturation on T cell responses. Using resting $\mathrm{DC}, \mathrm{Mucl}^{+/+} \mathrm{DC} / \mathrm{T}$ cell co-cultures secreted low amounts of TNF- $\alpha$ that was enhanced on stimulation of naive CD4+ T cells with LPS or flagellin-exposed DC

J Innate Immun 2010;2:123-143 

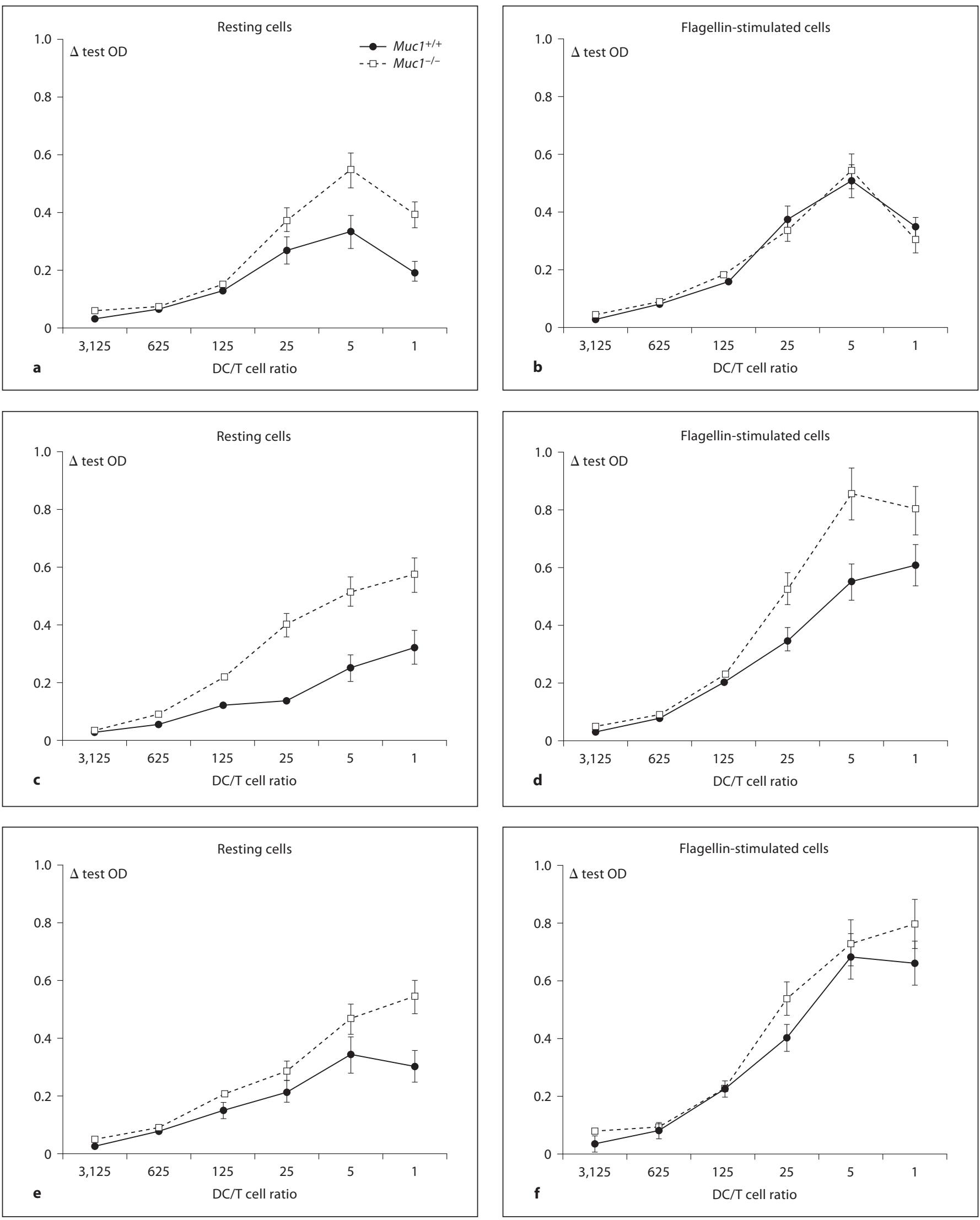
( $\mathrm{p}<0.01$; fig. 10a). While co-cultures using $\mathrm{Mucl}^{-/-} \mathrm{DC}$ promoted a similar pattern of cytokine secretion, the amount of TNF- $\alpha$ secreted was markedly greater as compared with co-cultures using $\mathrm{Mucl}^{+/+}$DC (fig. 10a). In contrast, IL-12p40 secretion was much higher in co-cultures of CD4+ T cells and $\mathrm{Mucl}^{+/+} \mathrm{DC}$ as compared with $\mathrm{Mucl}^{-{ }^{-}}$DC, even after stimulation of those DC with LPS or flagellin ( $\mathrm{p}<0.05$; fig. 10b).

The secretion of IFN- $\gamma$ (a Th1 type cytokine) followed a similar pattern as seen for TNF- $\alpha$ production in $\mathrm{DC} / \mathrm{T}$ cell co-cultures (fig. 10c). Under conditions of pre-stimulating $\mathrm{MuCl}^{-1-}$ DC with LPS or flagellin, we observed greater levels of IFN- $\gamma$ secreted from the co-culture as compared with $\mathrm{Mucl}^{+/+}$DC-stimulated CD4+ T cells ( $\mathrm{p}<0.05$; fig. 10c). However, in both $\mathrm{Mucl}^{-/-} \mathrm{DC}$ and wild-type counterparts, both LPS and flagellin enhanced the ability of DC to promote increased IFN- $\gamma$ secretion in the co-culture $(\mathrm{p}<0.01)$. This was in sharp contrast to the secretion of IL-13, which was only significantly increased in DC/T cell co-cultures using flagellin-stimulated wild-type $\mathrm{Mucl}^{+/+}$or to a lesser degree $\mathrm{Mucl}^{-/-} \mathrm{DC}$ (fig. 10d).

Using multiplex cytokine array assays, we repeated these studies using naive CD62L+CD4+ T cells co-cultured with freshly isolated primary lung or splenic DC ex vivo (table 1). In many respects, stimulation of $\mathrm{CD} 4+\mathrm{T}$ cells in co-culture with lung or spleen $\mathrm{Mucl}^{-/-} \mathrm{DC}$ and wild-type counterparts recapitulated many of the cytokine secretion readouts that we observed using BM-DC. In the case of TNF- $\alpha$ and IL- 6 secretion, both LPS and flagellin pre-stimulated DC provoked enhanced levels of

Fig. 9. Quantitation of naive CD4+ T cell proliferation on contact with resting (a) or flagellin-activated (b) $\mathrm{Mucl}^{+/+}$and $\mathrm{Mucl}^{-{ }_{-}^{-}}$ BM-DC. Resting or flagellin-activated DC were reciprocally titrated (1 to 5 dilution series) against a constant number of naive alloreactive murine CD4+ CD62L+ T cells. T cell proliferation was enumerated by pulsing co-cultures with bromodeoxyuridine (BrdU) for the final $18 \mathrm{~h}$ of culture of a 4 -day co-culture. In addition, stimulation of naive CD4+CD62L+ T cells by $\mathrm{Mucl}^{+/+}$and $\mathrm{Mucl}^{-/-}$primary lung DC (c, d) as well as primary splenic DC (e, f) is also shown for comparison. We used a colorimetric immunoassay for the quantitation of cell proliferation, based on the measurement of BrdU incorporation during DNA synthesis according to the manufacturer's instructions (Roche Molecular Biochemicals, Mannheim, Germany; see Materials and Methods). Data are expressed as mean $\Delta$ OD (at an absorbance wavelength of $450 \mathrm{~nm}$ and a reference wavelength of $690 \mathrm{~nm}) \pm 1$ standard deviation about the mean (product of 5 independent proliferation experiments for BM-DC and 3 independent experiments for lung and spleen DC).

Muc1 Deletion Activates Dendritic Cells both of these cytokines to be secreted by co-cultures of CD4+ T cells and lung or spleen DC, with significantly more TNF- $\alpha$ and IL- 6 secreted using CD4+ T cells cocultured with $\mathrm{Mucl}^{-/-}$DC compared to wild-type spleen or lung DC $(\mathrm{p}<0.05$; table 1$)$. However, while the secretion of IL-12p40 was augmented in co-cultures of CD4+ T cells and either LPS or flagellin pre-stimulated lung or spleen DC (table 1), $\mathrm{Mucl}^{-1-}$ DC promoted much lower amounts of IL-12p40 to be secreted in co-culture than their wild-type counterparts (table 1), similar to the case of BM-DC (fig. 10b). Flagellin-exposed $\mathrm{Mucl}^{-/-}$spleen and lung DC also induced the secretion of more IFN- $\gamma$ (and less IL-13) in co-culture with naive T cells than wildtype DC ( $p<0.05$; table 1$)$, similar to results obtained using BM-DC (fig. 10c, d).

\section{Discussion}

In this study, deletion of the membrane glycoprotein Mucl results in dysregulated DC activation and generally heightened responses to the TLR ligands lipopolysaccharide and flagellin. Mucl-deficient DC not only secreted more inflammatory cytokines than wild-type DC but also promoted a Th1-like pattern of cytokine production in co-culture with naive allogeneic T cells, especially after flagellin-driven maturation. We observed strikingly concordant results using 3 different sources of DC, namely those derived from bone marrow precursors in vitro, or freshly isolated primary lung and spleen DC. Although there were some cell type-specific differences in the expression of surface markers or secretion of cytokines when comparing wild-type with Mucl-deficient DC, our data strongly implicate Mucl as a novel negative regulator of innate immune responses, and suggest that Mucl plays a previously under-appreciated role in down-modulating TLR-dependent DC activation.

An unexpected observation was that deletion of Mucl attenuated the ability of DC to take up exogenous antigen, modeled in our study by the uptake of FITC-conjugated dextran. We confirmed findings using standard flow cytometry with the new technique of imaging fluorescence cytofluorography, which allows rapid quantification of internalized probes (fig. 3). One possibility is that Mucl-deficient DC were in a preactivated state and had consequently down-regulated cell surface receptors involved in endocytosis. However, the observation that Mucl deficiency did not alter constitutive binding of FITC-dextran to the DC surface argues against this sim- 

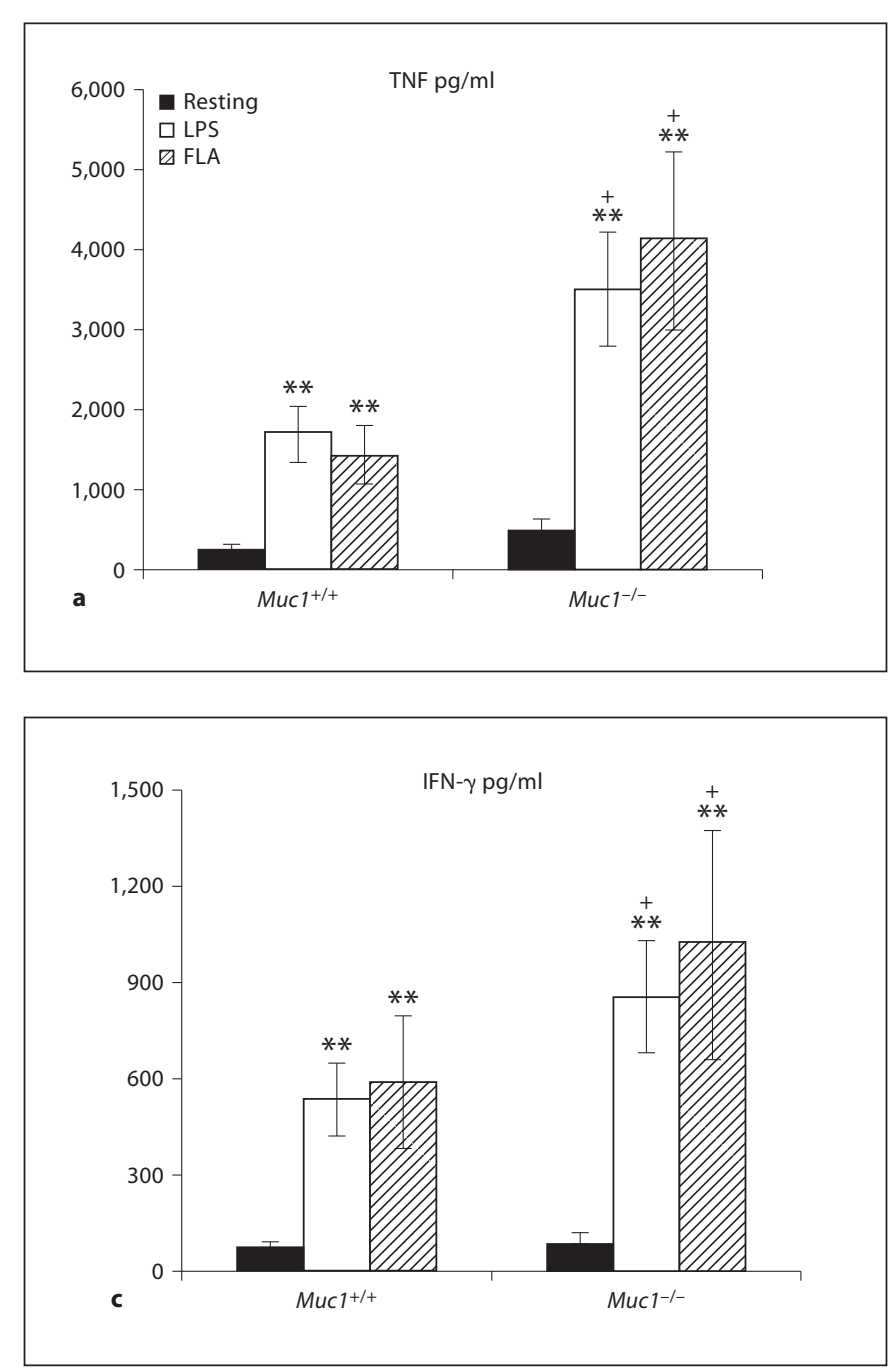

Fig. 10. Quantitation of cytokine production in co-cultures of naive CD4+ CD62L+ T cells with resting, LPS or flagellin-activated $\mathrm{MuCl}^{+/+}$and $\mathrm{MuCl}^{-/-} \mathrm{BM}-\mathrm{DC}$. Culture supernatants were harvested after 4 days from the DC and naive CD4+ CD62L+ T cell cocultures (at a 1:5 ratio) and quantified for cytokine elaboration by multiplex cytokine array analysis (see Materials and Methods).

ple explanation (fig. 3 and data not shown). Alternatively, Mucl may play an essential and non-redundant role in antigen capture and/or uptake by endocytic or phagocytic pathways. This would be in keeping with the observation that Mucl is endocytosed by a clathrin-mediated mechanism [30, 31], which would result in internalization of any exogenous antigen bound to its extended and highly glycosylated extracellular domains. Interestingly, similar to other endocytic receptors, endosomal Mucl can be recycled and re-expressed on the cell membrane [32]. Alternatively, Mucl could target antigen uptake in-
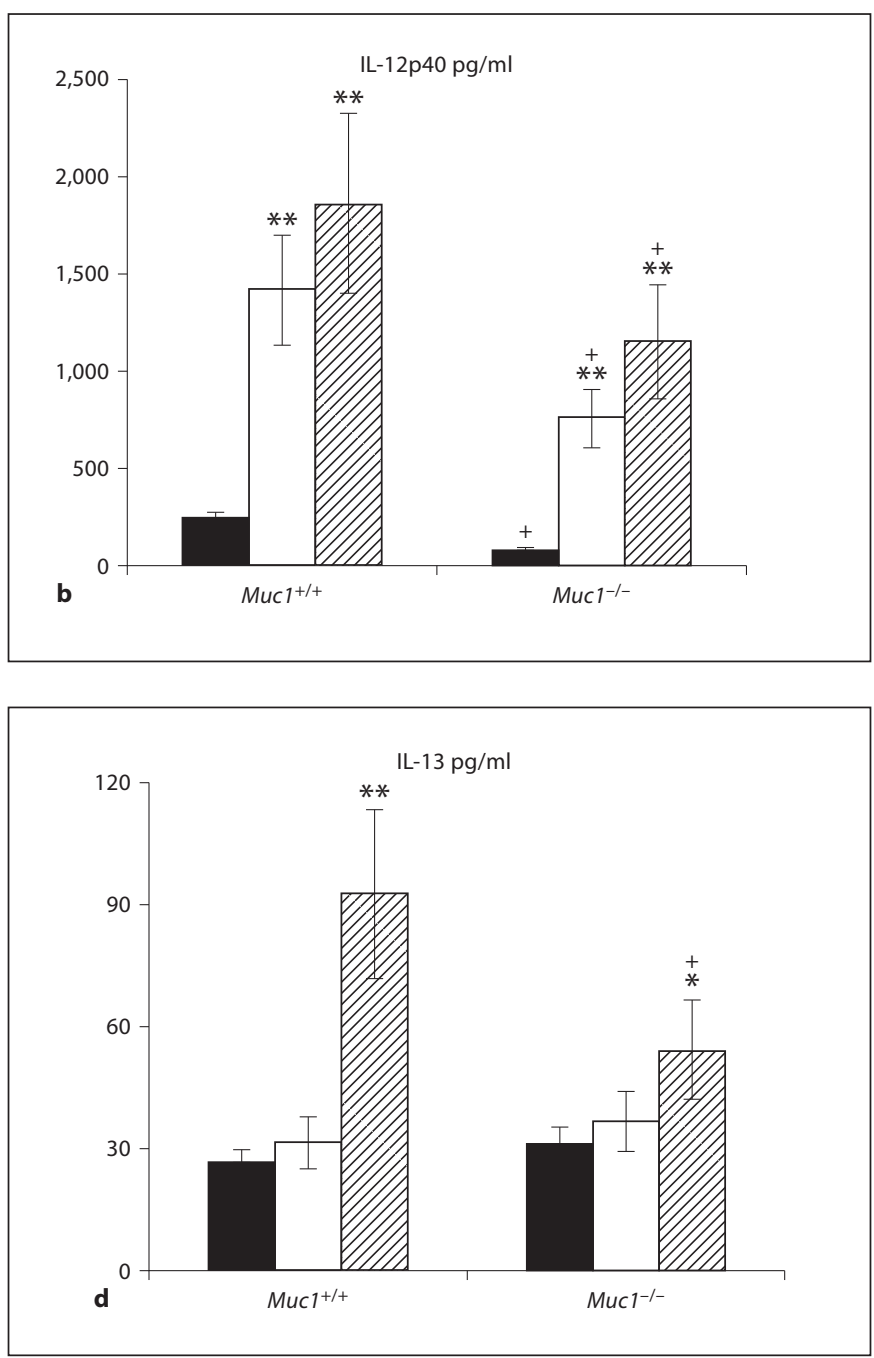

The following cytokines were measured: TNF- $\alpha$ (a), IL-12p40 (b), IFN- $\gamma(\mathbf{c})$ and IL-13 (d). Data are pg/ml of the DC/T cell co-culture \pm 1 standard deviation about the mean. Alpha values: ${ }^{*} \mathrm{p}<$ $0.05 ;{ }^{* *} \mathrm{p}<0.01 ;^{+} \mathrm{p}<0.05$, all wild-type vs. knockout DC (average of 5 independent proliferation experiments for BM-DC). FLA = Flagellin stimulated.

directly by binding C-type lectins [30, 33]. Future studies will be needed to distinguish between these and other possibilities, and determine whether Mucl targets extracellular antigen to different intracellular compartments or affects antigen processing in dendritic cells.

We found that Mucl deficiency differentially affected DC activation in response to 2 key TLR ligands. For example, whereas LPS up-regulated the expression of costimulatory molecules on both wild-type and $\mathrm{MuCl}^{-/-}$ BM-DC, stimulation with flagellin only increased costimulatory molecule expression on wild-type DC (fig. 4). 
Table 1. Cytokine secretion by co-cultures of lung or splenic DC-stimulated naive CD4+ T cells

\begin{tabular}{|c|c|c|c|c|c|c|c|c|c|c|c|c|c|c|c|}
\hline & \multicolumn{3}{|l|}{ TNF } & \multicolumn{3}{|l|}{ IL-12 } & \multicolumn{3}{|l|}{ IFN- $\gamma$} & \multicolumn{3}{|l|}{ IL-13 } & \multicolumn{3}{|l|}{ IL-6 } \\
\hline \multicolumn{16}{|c|}{ Lung DC } \\
\hline \multicolumn{16}{|c|}{ Splenic DC } \\
\hline WT & $\begin{array}{l}16.3 \\
(5.8)\end{array}$ & $\begin{array}{l}142.3 \\
(36.9)^{*}\end{array}$ & $\begin{array}{l}157.6 \\
(42.2)^{*}\end{array}$ & $\begin{array}{l}8.7 \\
(5.5)\end{array}$ & $\begin{array}{l}358.7 \\
(74.8)^{*}\end{array}$ & $\begin{array}{l}295.3 \\
(89.4)^{*}\end{array}$ & $\begin{array}{l}21.2 \\
(19.7)\end{array}$ & $\begin{array}{l}213.4 \\
(43.7)^{*}\end{array}$ & $\begin{array}{l}169.8 \\
(66.8)^{*}\end{array}$ & $\begin{array}{l}12.2 \\
(7.4)\end{array}$ & $\begin{array}{l}43.3 \\
(19.6)^{*}\end{array}$ & $\begin{array}{l}102.8 \\
(39.3)^{*}\end{array}$ & $\begin{array}{l}3.8 \\
(8.5)\end{array}$ & $\begin{array}{l}338.4 \\
(76.9)^{*}\end{array}$ & $\begin{array}{l}197.4 \\
(67.8)^{*}\end{array}$ \\
\hline $\mathrm{KO}$ & $\begin{array}{l}29.3 \\
(8.6)\end{array}$ & $\begin{array}{l}523.8 \\
(109)^{* *,+}\end{array}$ & $\begin{array}{l}438.7 \\
(133)^{* *,+}\end{array}$ & $\begin{array}{l}10.1 \\
(7.4)\end{array}$ & $\begin{array}{l}176.6 \\
(50.3)^{* *,+}\end{array}$ & $\begin{array}{l}204.6 \\
(33.6)^{* *,+}\end{array}$ & $\begin{array}{l}92.2 \\
(47.3)^{+}\end{array}$ & $\begin{array}{l}271.2 \\
(62.6)^{* *,+}\end{array}$ & $\begin{array}{l}439.1 \\
(113)^{* *++}\end{array}$ & $\begin{array}{l}17.7 \\
(11.2)\end{array}$ & $\begin{array}{l}37.2 \\
\text { (19.3) NS }\end{array}$ & $\begin{array}{l}76.8 \\
(30)^{*}\end{array}$ & $\begin{array}{l}34.2 \\
(16.7)\end{array}$ & $\begin{array}{l}1,077 \\
(344)^{* *++}\end{array}$ & $\begin{array}{l}344.8 \\
(108)^{* *,+}\end{array}$ \\
\hline
\end{tabular}

In addition to assessing cytokine elaboration from a BM-DC and T cell co-culture system, we also studied the comparative secretion of the same cytokines (TNF- $\alpha$, IL-12p40, IFN- $\gamma$ and IL-13) as well as IL- 6 by multiplex cytokine array analysis (see Materials and Methods) from primary lung or primary splenic $\mathrm{Mucl}^{+/+}$and $\mathrm{Mucl}^{-/-} \mathrm{DC}$. Data are $\mathrm{pg} / \mathrm{ml}$ of the DC/T cell co-culture \pm 1 standard deviation about the mean (shown in parentheses).
$\mathrm{R}=$ Resting DC that were unstimulated; L = LPS $(100 \mathrm{ng} / \mathrm{ml})$ stimulated cells; F = flagellin- $(100 \mathrm{ng} / \mathrm{ml})$ stimulated cells; NS = no statistically significant difference between stimulated and resting cells in the co-culture.

Alpha values: ${ }^{*} \mathrm{p}<0.05 ;{ }^{* *} \mathrm{p}<0.01 ;{ }^{+} \mathrm{p}<0.05$, all wild-type vs. knockout DC (product of 3 independent experiments for lung and spleen DC).
This may have been due to constitutively greater expression of these molecules (CD40, CD80 and CD86) at baseline in the absence of Mucl, possibly reflecting in part activation of $\mathrm{Mucl}^{-/-} \mathrm{BM}-\mathrm{DC}$ during differentiation and expansion in vitro. In support of this notion, we observed constitutively greater secretion of IL-6, TNF- $\alpha$ (fig. 7), and VEGF from $\mathrm{Mucl}^{-/-} \mathrm{BM}$-DC compared to their wildtype counterparts, whereas freshly isolated primary lung and spleen DC from Mucl-deficient mice did not constitutively secrete more cytokines than their wild-type counterparts (with the exception of IL-12p40; fig. 8). In contrast, whereas LPS-induced IL-12p40 and TNF- $\alpha$ secretion were similar in both wild-type and Mucl-deficient DC, flagellin stimulated substantially greater amounts of these 2 pro-inflammatory cytokines in Mucl-deficient BM-DC compared to their wild-type counterparts (fig. 7a, b). The dissociation between flagellin-induced co-stimulatory molecule expression and cytokine secretion in BM-DC could be explained by differential coupling of TLR5 to downstream adaptor molecules. Since co-stimulatory molecule expression is largely independent of Myd88 and instead relies on other pathways (e.g. Trif/Tram) [6,34], one interesting possibility is Mucl may preferentially inhibit coupling of TLR5 to MyD88.

Experiments using primary lung and spleen CD11c+ DC confirmed the key observations obtained using bone marrow DC differentiated in vitro. For example, expression of CD54, an important co-stimulatory molecule/ad- hesion receptor, was significantly greater on primary Muc1-deficient DC than wild-type DC both at baseline and following TLR4- and TLR5-induced activation (fig. $5,6)$. Similarly, both bone marrow-derived DC and primary spleen and lung DC from $\mathrm{Mucl}^{-/-}$mice generally secreted more IL-6, IL-12p40, and TNF- $\alpha$ than their wild-type counterparts, whereas the opposite pattern was true in the case of the anti-inflammatory cytokine IL-10 (fig. 7, 8). This phenotype of Mucl-deficient DC (i.e. greater co-stimulatory molecule expression, IL-12 ${ }^{\text {hi }}$, IL$10^{\mathrm{lo}}$ ) likely helps explain the greater capacity of these DC to stimulate naive $\mathrm{T}$ cells in alloreactive co-culture assays (fig. 9, 10; table 1). We did not define the precise molecular mechanism(s) by which Mucl inhibits TLR-dependent DC activation in our study. We favor a model suggested in other cell types (e.g. tracheal epithelial cells, HEK292T cell line and RAW264.7 cells), in which the Muc1 intracytoplasmic C-terminal domain competes with TLRs for binding of key intracellular adaptors such as GSK-3B or c-Src $[22,35]$. Future studies will be needed to extend this model to DC.

Our results have potential implications for understanding the escape of immune surveillance by cancer cells, many of which are known to express abundant cell surface Mucl [36]. In addition to serving as a potential target for cancer immunotherapy, Mucl has been shown to inhibit the function of immune cells including DC by still as yet undetermined mechanisms [37, 38]. Our data suggest that inhibiting Muc1 may boost anti-tumor im- 
munity not only by blocking Mucl on tumor cells but also on DC. It is tempting to speculate that Mucl on tumor cells may interact with Mucl on DC via homotypic adhesion, but this requires formal demonstration. In keeping with an inhibitory role for Mucl on DC activation, we found that $\mathrm{MuCl}^{-1-} \mathrm{DC}$ were more potent stimulators of naive $\mathrm{CD} 4+\mathrm{T}$ cell proliferation as compared with their $\mathrm{Mucl}^{+/+}$DC counterparts (fig. 5). This prolific ability of $\mathrm{Mucl}^{-/-}$DC to stimulate CD4+ T cell proliferation was associated with an enhanced constitutive expression of co-stimulatory molecules (fig. 4-6) and secretion of proinflammatory cytokines (fig. 7, 8). Importantly, Mucl deficiency also strikingly affected the ability of DC to activate $\mathrm{T}$ cells as determined by the patterns of cytokines produced during DC:T co-cultures. This was most apparent in the case of flagellin-stimulated DC, where deletion of Mucl on DC resulted in substantially greater secretion of both TNF- $\alpha$ and IFN- $\gamma$ in co-culture with wild-type $\mathrm{T}$ cells (fig. 10; table 1). This observation is reminiscent of the findings by Lu et al. [20] that pulmonary clearance of Pseudomonas aeruginosa is enhanced in $\mathrm{Mucl}^{-/-}$mice in association with higher TNF- $\alpha$ levels in the lung. Some of the effects of Mucl deficiency may be attributable to reduced IL-10 production, since IL-10 inhibits inflammatory cytokine secretion in its target cells. Interestingly, reduced DC-derived IL-10 was recently implicated in mediating protection from colitis in mice in response to bacterial pathogens [39]. It will be interesting in future studies to determine if Mucl contributes to this process. Whereas wild-type flagellin-stimulated DC induced $\sim 2$-fold more IL-13 secretion than resting DC in co-culture with T cells, this was not observed using $\mathrm{Mucl}^{-/-} \mathrm{DC}$. Thus flagellin induces a more Th1-like $\mathrm{T}$ cell phenotype in naive allogeneic T cells (high IFN- $\gamma$, low IL-13) in the absence of dendritic cell Mucl. Future studies in which the expression of Mucl on DC can be manipulated in vivo should provide insights into the role of this molecule in antigen-specific immune responses and $\mathrm{T}$ cell differentiation.

Given that $\mathrm{Mucl}^{-/-}$DC induced more T cell activation with a Th1-like phenotype in co-culture with T cells, we were surprised to observe that these cells secreted substantially less IL-12 than their wild-type counterparts in both resting and LPS or flagellin activated DC:T co-cultures (fig. 10; table 1). This suggests that Mucl regulates the ability of DC to influence Th differentiation in an IL12-dependent manner. Future studies will be needed to determine whether this involves other secreted factors or contact-dependent mechanisms. Interestingly, $\mathrm{Mucl}^{-/-}$ DC secreted markedly greater levels of VEGF than their wild-type counterparts constitutively, and this was further augmented in response to flagellin and LPS. VEGF plays an important role not only in vascular remodeling but also in modulating immune function and DC activation [40,41]. Since the effects of VEGF on DC activation are generally inhibitory [41-43], this suggests that enhanced DC activation in the absence of Mucl is not simply due to autocrine secretion of VEGF.

We conclude that deletion of the cell surface molecule Mucl results in altered responses of DC to 2 key innate immune receptors, TLR4 and TLR5. Our studies strongly suggest that Mucl is a previously under-appreciated modulator of DC responses to bacterial infections and tumor cells, and support the idea that Mucl regulates cross-talk between innate and adaptive immune systems.

\section{Acknowledgements}

This research was supported in part by a pilot project grant from the NIH (NIEHS P30 ES03819 to M.A.W.), a grant from NIH (AI-72291 to E.P.L.), and the University of Rochester Department of Medicine. Additional sources of funding: NIH R01 HL071933; EPA R82672401; NIEHS P01 ES09606.

\section{References}

1 Vermaelen K, Pauwels R: Pulmonary dendritic cells. Am J Respir Crit Care Med 2005; 172:530-551

-2 Mellman I, Steinman RM: Dendritic cells: specialized and regulated antigen processing machines. Cell 2001;106:255-258.

$\checkmark 3$ Lanzavecchia A, Sallusto F: Antigen decoding by T lymphocytes: from synapses to fate determination. Nat Immunol 2001;2:487492 .
-4 Takeda K, Kaisho T, Akira S: Toll-like receptors. Annu Rev Immunol 2003;21:335-376.

5 Beutler B: Inferences, questions and possibilities in Toll-like receptor signalling. $\mathrm{Na}$ ture 2004;430:257-263.

6 Kaisho T, Hoshino K, Iwabe T, Takeuchi O, Yasui T, Akira S: Endotoxin can induce MyD88-deficient dendritic cells to support $\mathrm{T}(\mathrm{h}) 2$ cell differentiation. Int Immunol 2002; 14:695-700.
-7 Means TK, Hayashi F, Smith KD, Aderem A, Luster AD: The Toll-like receptor 5 stimulus bacterial flagellin induces maturation and chemokine production in human dendritic cells. J Immunol 2003;170:5165-5175.

$>8$ Eisenbarth SC, Piggott DA, Huleatt JW, Visintin I, Herrick CA, Bottomly K: Lipopolysaccharide-enhanced, toll-like receptor 4-dependent T helper cell type 2 responses to inhaled antigen. J Exp Med 2002;196:1645-1651. 
-9 Sha Q, Truong-Tran AQ, Plitt JR, Beck LA, 22 Ueno K, Koga T, Kato K, Golenbock DT, GenSchleimer RP: Activation of airway epithelial cells by toll-like receptor agonists. Am J Respir Cell Mol Biol 2004;31:358-364.

10 Chang JF, Zhao HL, Phillips J, Greenburg G: The epithelial mucin, MUC1, is expressed on resting $\mathrm{T}$ lymphocytes and can function as a negative regulator of $\mathrm{T}$ cell activation. Cell Immunol 2000;201:83-88.

- 11 Agrawal B, Krantz MJ, Parker J, Longenecker BM: Expression of MUC1 mucin on activated human T cells: implications for a role of MUC1 in normal immune regulation. Cancer Res 1998;58:4079-4081.

-12 Cloosen S, Thio M, Vanclee A, van Leeuwen EB, Senden-Gijsbers BL, Oving EB, Germeraad WT, Bos GM: Mucin-1 is expressed on dendritic cells, both in vitro and in vivo. Int Immunol 2004;16:1561-1571.

-13 Wykes M, MacDonald KP, Tran M, Quin RJ, Xing PX, Gendler SJ, Hart DN, McGuckin MA: MUC1 epithelial mucin (CD227) is expressed by activated dendritic cells. J Leukoc Biol 2002;72:692-701.

-14 Lillehoj EP, Kim H, Chun EY, Kim KC: Pseudomonas aeruginosa stimulates phosphorylation of the airway epithelial membrane glycoprotein Mucl and activates MAP kinase. Am J Physiol Lung Cell Mol Physiol 2004; 287:L809-L815.

$\checkmark 15$ Lillehoj EP, Kim BT, Kim KC: Identification of Pseudomonas aeruginosa flagellin as an adhesin for Mucl mucin. Am J Physiol Lung Cell Mol Physiol 2002;282:L751-L756.

16 Gewirtz AT, Navas TA, Lyons S, Godowski PJ, Madara JL: Cutting edge: bacterial flagellin activates basolaterally expressed TLR 5 to induce epithelial proinflammatory gene expression. J Immunol 2001;167:1882-1885.

$\checkmark 17$ Hayashi F, Smith KD, Ozinsky A, Hawn TR, Yi EC, Goodlett DR, Eng JK, Akira S, Underhill DM, Aderem A: The innate immune response to bacterial flagellin is mediated by Toll-like receptor 5. Nature 2001;410:10991103.

- 18 Smith KD, Andersen-Nissen E, Hayashi F, Strobe K, Bergman MA, Barrett SL, Cookson BT, Aderem A: Toll-like receptor 5 recognizes a conserved site on flagellin required for protofilament formation and bacterial motility. Nat Immunol 2003;4:1247-1253.

-19 Andersen-Nissen E, Smith KD, Bonneau R, Strong RK, Aderem A: A conserved surface on Toll-like receptor 5 recognizes bacterial flagellin. J Exp Med 2007;204:393-403.

$\checkmark 20 \mathrm{Lu} \mathrm{W}$, Hisatsune A, Koga T, Kato K, Kuwahara I, Lillehoj EP, Chen W, Cross AS, Gendler SJ, Gewirtz AT, Kim KC: Cutting edge: enhanced pulmonary clearance of Pseudomonas aeruginosa by Muc1 knockout mice. J Immunol 2006;176:3890-3894.

-21 Kato K, Lu W, Kai H, Kim KC: Phosphoinositide 3-kinase is activated by MUC1 but not responsible for MUC1-induced suppression of Toll-like receptor 5 signaling. Am J Physiol Lung Cell Mol Physiol 2007;293:L686-L692. dler SJ, Kai H, Kim KC: MUC1 mucin is a negative regulator of toll-like receptor signaling. Am J Respir Cell Mol Biol 2008;38:263-268.

23 Williams MA, Porter M, Horton M, Guo J, Roman J, Williams D, Breysse P, Georas SN: Ambient particulate matter directs nonclassic dendritic cell activation and a mixed $\mathrm{T}(\mathrm{H}) 1 / \mathrm{T}(\mathrm{H}) 2$-like cytokine response by naive CD4(+) T cells. J Allergy Clin Immunol 2007;119:488-497.

24 Lutz MB, Kukutsch N, Ogilvie AL, Rössner S, Koch F, Romani N, Schuler G: An advanced culture method for generating large quantities of highly pure dendritic cells from mouse bone marrow. J Immunol Methods 1999;223:77-92.

25 Sallusto F, Lanzavecchia A: Efficient presentation of soluble antigen by cultured human dendritic cells is maintained by granulocyte/ macrophage colony-stimulating factor plus interleukin 4 and downregulated by tumor necrosis factor alpha. J Exp Med 1994;179: 1109-1118.

26 Williams MA, Rangasamy T, Bauer SM, Killedar S, Karp M, Kensler TW, Yamamoto M, Breysse P, Biswal S, Georas SN: Disruption of the transcription factor Nrf2 promotes pro-oxidative dendritic cells that stimulate Th2-like immunoresponsiveness upon activation by ambient particulate matter. J Immunol 2008; 181:4545-4559.

27 George TC, Fanning SL, Fitzgerald-Bocarsly P, Medeiros RB, Highfill S, Shimizu Y, Hall BE, Frost K, Basiji D, Ortyn WE, Morrissey PJ, Lynch DH: Quantitative measurement of nuclear translocation events using similarity analysis of multispectral cellular images obtained in flow. J Immunol Methods 2006; 311:117-129.

28 Ortyn WE, Hall BE, George TC, Frost K, Basiji DA, Perry DJ, Zimmerman CA, Coder D, Morrissey PJ: Sensitivity measurement and compensation in spectral imaging. Cytometry 2006;69:852-862.

29 Wang JC, Kobie JJ, Zhang L, Cochran M, Mosmann TR, Ritchlin CT, Quataert SA: An 11-color flow cytometric assay for identifying, phenotyping, and assessing endocytic ability of peripheral blood dendritic cell subsets in a single platform. J Immunol Methods 2009;341:106-116.

30 Napoletano C, Rughetti A, Agervig Tarp MP, Coleman J, Bennett EP, Picco G, Sale P, Denda-Nagai K, Irimura T, Mandel U, Clausen H, Frati L, Taylor-Papadimitriou J, Burchell J, Nuti M: Tumor-associated Tn-MUC1 glycoform is internalized through the macrophage galactose-type $\mathrm{C}$-type lectin and delivered to the HLA class I and II compartments in dendritic cells. Cancer Res 2007;67: 8358-8367.

31 Kinlough CL, Poland PA, Bruns JB, Harkleroad KL, Hughey RP: MUC1 membrane trafficking is modulated by multiple interactions. J Biol Chem 2004;279:53071-53077.
32 Kinlough CL, McMahan RJ, Poland PA, Bruns JB, Harkleroad KL, Stremple RJ, Kashlan OB, Weixel KM, Weisz OA, Hughey RP: Recycling of MUC1 is dependent on its palmitoylation. J Biol Chem 2006;281:1211212122.

33 Sancho D, Joffre OP, Keller AM, Rogers NC, Martínez D, Hernanz-Falcón P, Rosewell I, Reis e Sousa C: Identification of a dendritic cell receptor that couples sensing of necrosis to immunity. Nature 2009;458:899-903.

34 Trinchieri G, Sher A: Cooperation of Tolllike receptor signals in innate immune defence. Nat Rev Immunol 2007;7:179-190.

35 Ueno K, Koga T, Kato K, Golenbock DT, Gendler SJ, Kai H, Kim KC: MUC1 mucin is a negative regulator of toll-like receptor signaling. Am J Respir Cell Mol Biol 2008;38: 263-268.

36 Singh R, Bandyopadhyay D: MUC1: a target molecule for cancer therapy. Cancer Biol Ther 2007;6:481-486.

- 37 Carlos CA, Dong HF, Howard OM, Oppenheim JJ, Hanisch FG, Finn OJ: Human tumor antigen MUC1 is chemotactic for immature dendritic cells and elicits maturation but does not promote Th1 type immunity. J Immunol 2005;175:1628-1635.

38 Rughetti A, Pellicciotta I, Biffoni M, Backstrom M, Link T, Bennet EP, Clausen H, Noll T, Hansson GC, Burchell JM, Frati L, TaylorPapadimitriou J, Nuti M: Recombinant tumor-associated MUC1 glycoprotein impairs the differentiation and function of dendritic cells. J Immunol 2005; 174:7764-7772.

39 Mazmanian SK, Round JL, Kasper DL: A microbial symbiosis factor prevents intestinal inflammatory disease. Nature 2008;453: 620-625.

40 Lee CG, Link H, BalukP, Homer RJ, Chapoval S, Bhandari V, Kang MJ, Cohn L, Kim K, McDonald DM, Elias JA: Vascular endothelial growth factor (VEGF) induces remodeling and enhances $\mathrm{TH} 2$-mediated sensitization and inflammation in the lung. Nat Med 2004;10:1095-1103.

41 Oyama T, Ran S, Ishida T, Nadaf S, Kerr L, Carbone DP, Gabrilovich DI: Vascular endothelial growth factor affects dendritic cell maturation through the inhibition of nuclear factor-kappa B activation in hemopoietic progenitor cells. J Immunol 1998; 160:12241232.

$42 \mathrm{Ohm}$ JE, Shurin MR, Esche C, Lotze MT, Carbone DP, Gabrilovich DI: Effect of vascular endothelial growth factor and FLT3 ligand on dendritic cell generation in vivo. J Immunol 1999;163:3260-3268.

43 Dikov MM, Ohm JE, Ray N, Tchekneva EE, Burlison J, Moghanaki D, Nadaf S, Carbone DP: Differential roles of vascular endothelial growth factor receptors 1 and 2 in dendritic cell differentiation. J Immunol 2005; 174 : 215-222. 